\title{
THE STATUS QUO OF TEACHER-TRAINING COURSES IN THE IRANIAN EFL CONTEXT: A FOCUS ON MODELS OF PROFESSIONAL EDUCATION AND DYNAMIC ASSESSMENT
}

\author{
AbBAS ALI REZAEE ${ }^{1}$ \& MAHSA GHANBARPOUR \\ University of Tehran (Iran)
}

\begin{abstract}
Given that Teacher-Training Courses (TTC's) have responsibility for assisting prospective teachers with building up a repertoire of technical \& pedagogic knowledge, the systematically evaluation of such courses is regarded as seminal (Lynch, 2003 and Peacock, 2009). Therefore, the present study is an attempt to (a) probe into the way professional expertise is acquired by preservice Iranian EFL teachers, (b) analyze the instructional content of TTC's currently held in Iran, with a focus on teachings on Dynamic Assessment (DA), and (c) examine preservice teachers' and TTC trainers' opinions about the TTC's. To this end, 9 purposefully selected TTC's were observed, employing participant observation, and content analyses were carried out on their syllabi. Also, 107 TTC participants filled out a questionnaire, and 14 TTC instructors were interviewed; the sampling of the TTC participants and instructors was nonprobability convenient. Results of descriptive statistics showed that accounting for $84.73 \%$ of all the instructional attempts, the craft model was the most frequently prevalent model of teacher learning. Content analyses and preservice teacher questionnaire results signified that writing skill was marginalized in all the courses, and none of them included instructions on DA in their syllabi. Open, selective, and axial coding as well as content analyses of the collected data gave rise to eight themes delineating major areas fueling the current research-practice divide in the TTC syllabi. Findings of the study provide an opportunity to examine the status quo, strengths, and weaknesses of the TTC's. The eight identified impediments to the employment of research in pedagogy could help reach a framework for factors that might induce TTC organizers to disregard the implication of relevant research findings for the courses they run.
\end{abstract}

Key words: Classroom assessment, dynamic assessment, models of professional education, models of teacher learning, teacher education, teacher-training.

\section{Introduction}

After the Second World War, learning English turned out to be pivotal to complying with the demands of the Brave New World (Huxley, 1932), and in tandem with the changing trends in the fields of psychology and linguistics and the observed alterations in learners' needs, frequent swings of the pendulum (CelceMurcia, 2001) have taken place with regard to language teaching methods and alternative approaches (Celce-Murcia, 2001; Larsen-Freeman \& Anderson, 2011; Richards \& Renandya, 2002; Richards \& Rodgers, 2001). As new language teaching methods were introduced, more responsibility for their effectiveness lied with teachers (Richards \& Rodgers, 2001). Moreover, the postmethod condition (Kumaravadivelu, 1994, 2001, 2003) attached wider significance to the value of empowering teachers with cumulative knowledge, skill, and autonomy, and Prabhu (1990) made the point that it is, in fact, a teacher's personal sense of plausibility about teaching that renders the act of teaching productive, and methods, by themselves, cannot guarantee learning outcomes.

Therefore, the agency of teachers came to the fore of the teaching process more than ever before, and a number of teachers' attributes such as their identity (Miller, 2009), their mental lives (Walberg, 1977),

\footnotetext{
1 E-mail: ghanbarpour@alumni.ut.ac.ir
} 
teacher cognition (Borg, 2003; Freeman, 2002), teachers' characteristics, beliefs, behaviors, and assumptions (Chacon, 2005; Gencer \& Cakiroglu, 2007; Pajares, 1992; Williams \& Burden, 1997) have been researched into during the past score of years. Also, a plethora of research has been conducted on teacher-training and teachers' professional development. To exemplify, studies have delved into issues like reflective practice (Burton, 2009; Johnson \& Kroksmark, 2004; Taggart \& Wilson, 2005), critical pedagogy (Hawkins \& Norton, 2009; Norton, 2005; Pavlenko, 2003), and teachers' knowledge about language (Bartels, 2009; Haider \& Frensch, 1996); the aforementioned trends have shaped the way Second Language Teacher Education (SLTE) is now realized; on the practical side, all such studies are aimed at informing language teachers and/or other stakeholders in SLTE about the findings of the conducted research on Second Language Acquisition (SLA).

It must be noted, however, that whether or not enough heed is paid to the findings of relevant ongoing SLA research in the field of SLTE can be the subject of some lively debate. In other words, the argument that the type of technical knowledge found in teachers' practice of their profession, that is, 'pedagogic discourse', might be fundamentally different from the kind of technical knowledge delineated in published research into language learning and teaching, that is, 'research-based discourse', has been clearly buttressed by some scholars (Ellis, 2013; Freeman \& Johnson, 1998; Johnson, 2006). Similarly, the separation between research and practice/pedagogy and the bifurcation between researchers and practitioners in language teaching has been already acknowledged (Ellis, 2013; Schön, 1983; Wallace, 1991). Such concerns imply that teachers' practice of their profession is expected to be carried out in accord with the developments in the field, and scientific findings should be attended to in SLTE and included in the syllabi/teachings of TTC's. In view of the fact that teacher education programs, as "a central avenue of knowledge dissemination" (Ben-Peretz, 1994, p. 108), bring aspects of research knowledge to the attention of trainee teachers, focusing on TTC's held in the Iranian EFL context, this research attempts to discern models of teacher learning in TTC's in Iran, analyze their curricula, with a focus on teachings on DA, and investigate TTC attendees' and trainers' opinion about the courses they take and run.

\section{Review of the related literature}

\subsection{Language Teacher Education}

Teacher Education (TE) is known to be a rather multifarious, perplexing domain of inquiry (Borg, 2006). Despite the fact that in the 1980s, a number of research into TE looked into teachers' training in disciplinary knowledge, skills of classroom pedagogy, and teacher thinking (Clark \& Peterson, 1986; Freeman, 1982; Larsen-Freeman, 1983), from the late 1990s onwards, an expansion in research was seen into teachers' professional identities (Head \& Taylor, 1997), actual contexts of teaching practices (Flores \& Day, 2006), and the social dimension of both classroom interactions (Raviv, Raviv, \& Reisel, 1990; Ryan \& Patrick, 2001) and the very act of teaching (Fanselow, 1997). Research on TE has also delved into literature survey of the conducted research within the field of TE (Murray, Nuttall, \& Mitchell, 2008), the analysis of a multimode TE program that combines the major elements of both initial and in-service TE (Kynäslahti et al., 2006), and teachers' self-confidence, self-efficacy, professional identity, and professional development (Abednia, 2012; Mulholland, Dorman, \& Odgers, 2004; Shabani, Khatib, \& Ebadi, 2010; Warford, 2010).

In addition, some researchers have examined practicum supervision and mentoring (Hastings \& Squires, 2002; White \& Le Cornu, 2002; Yarrow, Millwater, \& Foster, 1996), efficacy of in-service TTC's (Yuen-Kwan, 1998), the application of teaching portfolios in TE (Berrill \& Addison, 2010), and teachers' reflective practices (Clarke, 2004; McLaughlin \& Hanifin, 1995; Risko, Vukelich, \& Roskos, 2002; Schön, 1987). Perspectives on teacher evaluation, including the what, whos, and whys of TE (Smith, 2005), alternative paradigms of TE (Zeichner, 1983), teacher expertise (Tsu, 2005), and the knowledge-base of language TE (Freeman \& Johnson, 1998, 2004) have also been investigated.

Applying an inductive paradigmatic analysis, Risko et al., (2008) provided a review and critique of empirical investigations conducted on teacher preparation and identified a number of pertinent limitations. Nuland (2011) spelled out an overview of Canadian preservice teacher education, an outline of some difficulties these programs encounter, and a summary of new teacher induction and mentoring activities. 
Working on Syrian EFL context, Albirini (2006) explored the attitudes of high school EFL teachers toward information and communication technologies. However, to date, almost no research has brought TTC's of the Iranian EFL context under scrutiny.

\subsection{Models of Professional Education}

Since "the intent of pre-service education programmes is to provide teacher candidates with the basic knowledge, skills and experiences needed to enter teaching" (Nuland, 2011, p. 411), professional education and teacher learning are indispensable parts of all such programs. Wallace (1991) chronicled three major models of teacher learning: the craft model, the applied science model, and the reflective model. According to Wallace (1991) and as presented in Figure 1., in the craft model, an expert or a 'master teacher' demonstrates how to teach or instructs the young trainee, and professional action, mainly seen as a craft, is learnt through imitation, practice and observation. According to Wallace (1991, p. 16), the craft model "does not handle satisfactorily the crucial element of the explosive growth of relevant scientific knowledge in recent times". The craft model can come under scrutiny in light of the assumptions of 'mentoring' in TE, which is considered a "key component in teacher education and professional development" (Delaney, 2012, p. 184) as well as "teacher retention" (Ibid, p. 185). Mentoring relationships can have a positive impact on mentees' early teaching experiences (Malderez, Hobson, Tracey, \& Kerr, 2007).

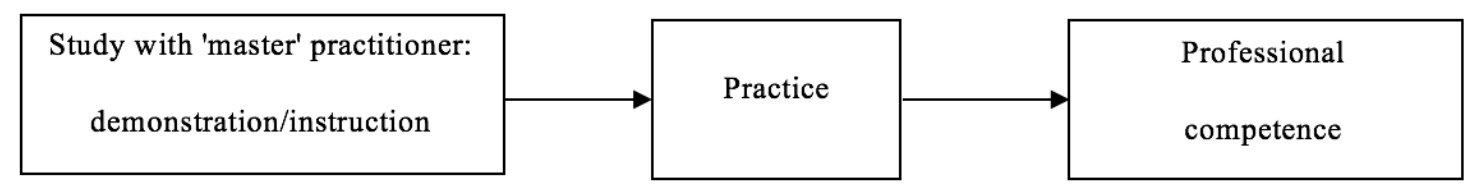

Figure.1. The craft model of professional education (Wallace, 1991, p. 6).

In the applied science model, which is also known as 'technical rationality', the trainee studies theories and research findings and amasses scientific knowledge about applied linguistics, and, later, puts them into practice in the context of classroom. As can be seen in Figure 2., through a one-way process, findings of scientific research are handed over to trainee teachers, who then put such solutions and finding into practice. Since practitioners do not really have a say in putting forward proposals to conduct certain experimentations to solve educational problems, the applied science model can result in a research-practice divide. 


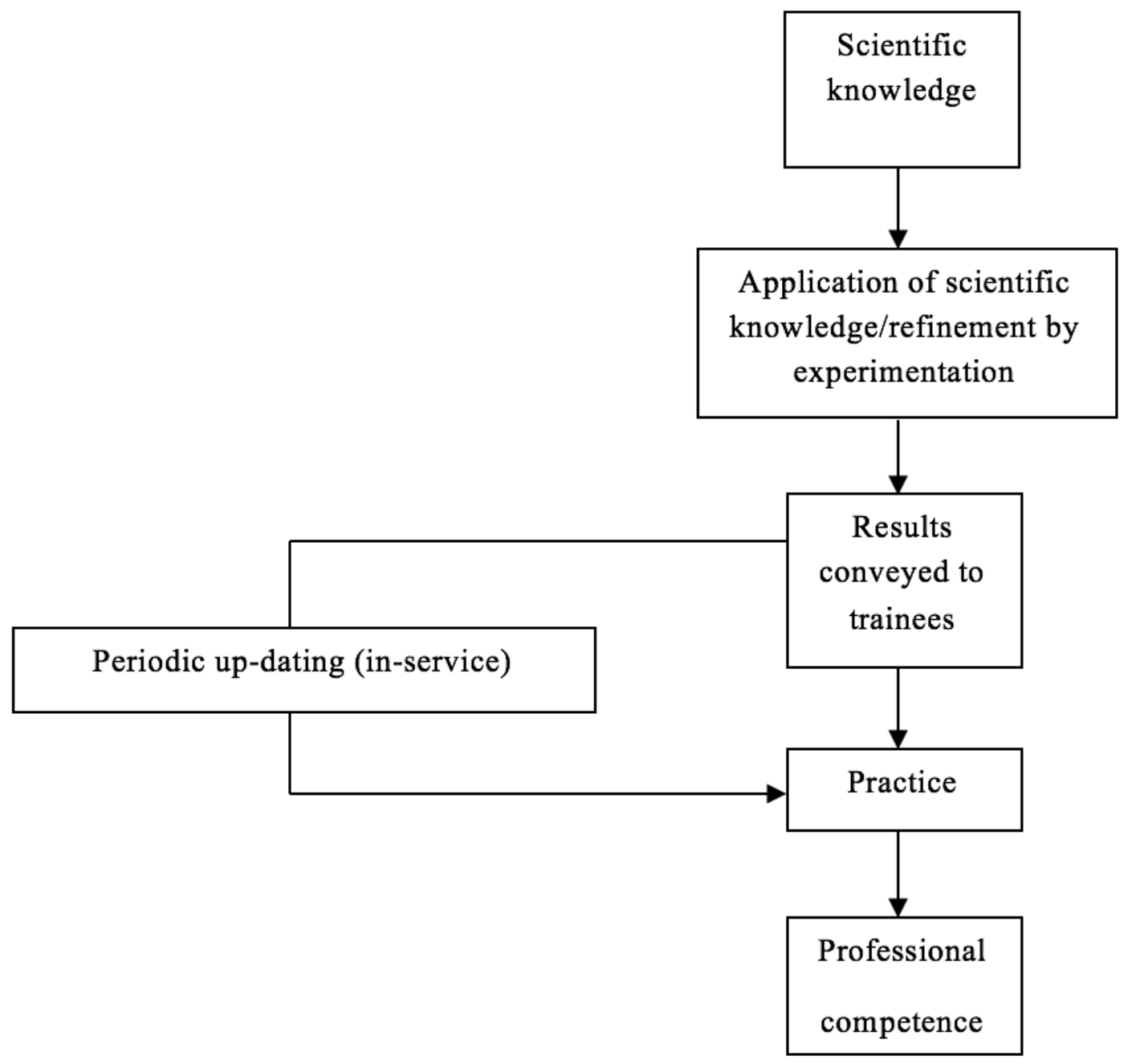

Figure 2. Applied science model (Wallace, 1991, p. 9).

The third model of teacher learning, the basic elements of which are depicted in Figure 3., is the reflective model. It is, in fact, a cycle aiming for continuous improvement and development of trainee teachers. In the first phase, trainees recall, observe, or teach lessons. They then reflect on the teaching practices either alone or in discussion with other colleagues or master teachers, and, finally, they try out the theories of teaching in practice. 


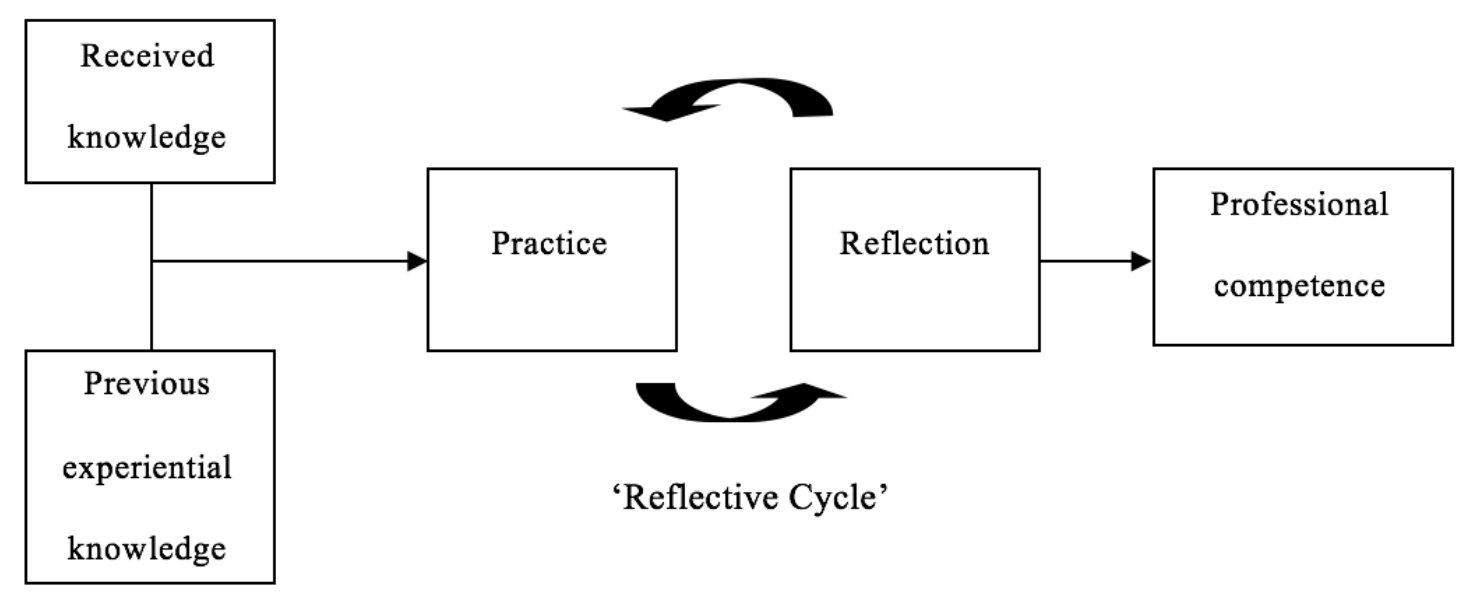

Figure 3. Reflective model (Wallace, 1991, p. 15).

Received knowledge includes the relevant theories, concepts, and research findings, which are parts of the content of teacher-training/education programs. Another kind of knowledge which is called experiential knowledge refers to (a) trainees' knowledge-in-action, which is developed by the practice of the profession and trainee teachers' immediate judgments and decisions, and (b) their reflections on their professional performance, which results in the conscious development of insights into knowledge-in-action.

\subsection{Dynamic Assessment (DA)}

Since the early 1980s, Socio-Cultural Theory (SCT), developed by Vygotsky, has become renowned for its potential to spell out the process of learners' cognitive development. Informed by the epistemological stance of sociocultural turn, its advocates have defined human learning as a dynamic, socially negotiated process which is interconnected with social and physical contexts (Johnson, 2006; Rogoff, 2003). In fact, Vygotsky (1998) conceives of abilities as emergent and dynamic traits, which can be modified during assessment procedures. According to the pedagogical approaches of DA, instruction -as a means of learner development support- and assessment, that is, a way of conceptualizing learners' ability, are to regarded as an integrated (Lantolf \& Thorne, 2006) and "dialectically fused" (Poehner, 2011a, p. 100) pursuit (see Poehner \& van Compernolle, 2011; Yeomans, 2008), which aims at promoting language development (Aljaafreh \& Lantolf, 1994).

Within the realm of second and foreign language acquisition, previous studies have delved into theoretical frameworks for the application of DA procedures to L2 assessment and pedagogy (Lantolf \& Poehner, 2004), the problem of assessment generalizability (Poehner, 2007), the relationship between assessment and the Zone of Proximal Development (ZPD), that is, learners' potential for future development (Allal \& Pelgrims Ducrey, 2000), and principled approaches to evaluating claims about learner abilities and their development (Poehner, 2011b). Moreover, a number of research has been carried out to address questions pertaining to the effectiveness of DA practices in promoting learners' language skills, that is, listening, writing, reading, and speaking, (Ableeva \& Lantolf, 2011; Dorfler, Golke, \& Artelt, 2009; Hill \& Sabet, 2009; Shrestha \& Coffin, 2012).

\subsection{Teachers' Diagnostic Competence}

According to Rea-Dickins (2004), "teaching involves assessment" (p. 249), and making decisions about learner progress, learner performance, and specific learning outcomes is an indispensable part of teachers' professional practice. Teachers constantly involve in classroom based assessment (Lynch, 2003) in one form or another, which is also referred to as teacher assessment. "They make selections based on their experience, on their understandings of learning, language development and of language proficiency itself, 
together with what they consider to be most appropriate and in the best interests of those they teach" (ReaDickins, 2004, p. 249).

In a sense, teachers are agents of assessment in assessing their students' abilities in classroom. So, teachers' diagnostic competence (Edelenbos \& Kubanek-German, 2004; Rea-Dickins, 2004) refers to their skills in arriving at grading decisions and constantly assessing the language abilities of their learners. Since teachers' understanding of assessment and language learning shape their actual assessment practices, TTC's can, at least partly, affect the efficacy of classroom assessment practices and teachers' conception of their roles as assessors by instructing preservice teachers on how to carry out classroom assessment, which is attended to in this research by raising the second research question.

To sum up, TTC's have responsibility for raising awareness in participants by assisting them with building up a repertoire of technical and pedagogic knowledge, the authenticity of which has been approved of by research. By so doing, such courses can bridge the gap between SLA discourse and pedagogic discourse. It is worth noting that by and large, SLA researchers have placed a premium on the language research-language pedagogy nexus (Ellis, 2010, 2013; Gass, 1995; Ishihara, 2010; Nuland, 2011; Nunan, 1991), and some scholars (Brownell, Griffin, Leko, \& Stephens, 2011; Ishihara, 2010) have opined that the nexus between theory and practice should be stronger in SLTE.

Despite its importance, the field of TE is regarded as "under-researched" (Peacock, 2009, p. 260), research into it is known to be "noticeably missing" (Freeman \& Johnson, 1998, p. 397), and a lack of research on evaluation procedures of language teacher education/training programs is acknowledged (Grosse, 1991). In view of the fact that to the researcher's knowledge, almost no research has examined the models of teacher learning and syllabi of preservice TTC's in Iran, the present study attempts to fill this gap by addressing the following questions:

1. What is the most frequently prevalent model of teacher learning in teacher-training courses held in Iran?

2. How are the curricula of teacher-training courses planned in Iran? Does the course content of teacher-training courses in Iran familiarize preservice teachers with the theories and principles underlying classroom assessment practices and $D A$ ?

3. What are teacher-training course attendees' and trainers' opinions about the TTC's?

\section{Methodology}

\subsection{Setting and Actors}

In qualitative studies, the place in which research takes place is referred to as the setting of the study, which is usually a part of a larger site, and those who are observed and interviewed are known as the actors of the study (see Creswell, 2009, p. 178). Nine TTC's offered by the central offices of well-established English language institutes in Iran, which constituted the sites of the present study, were purposefully selected because particularity rather than generalizability is an important characteristic of qualitative research. The selected TTC's, which were run either by one trainer or a team of two or more instructors (see Table 1), were observed, and their model of professional education and curricula were examined.

Apart from observations, 14 TTC instructors/trainers were called for an interview and were asked to reflect on the strengths and weaknesses of the courses as well as suggestions for improving them. Moreover, 107 course participants, that is, preservice English teachers, filled out a questionnaire. So, as depicted in Table 1, the participants or "actors" (see Creswell, 2009, p. 178) of the current study consisted primarily of TTC trainers and attendees. The sampling of the actors was not random but nonprobability convenient; that is, the course trainers and trainees were those who were involved in the TTC's which were held at the purposefully selected sites. 
Table 1. A Description of Actors of the Study

\begin{tabular}{|c|c|c|c|c|c|c|c|}
\hline \multirow{2}{*}{ Site } & \multicolumn{4}{|c|}{ TTC Attendees } & \multicolumn{3}{|c|}{ TTC Trainers } \\
\hline & Male & Female & $\begin{array}{l}\text { English } \\
\text { Majors }\end{array}$ & $\begin{array}{l}\text { Non- } \\
\text { English } \\
\text { Majors }\end{array}$ & Male & Female & $\begin{array}{l}\text { Educational } \\
\text { Background }\end{array}$ \\
\hline 1 & 6 & 11 & $\begin{array}{l}4 \text { (TEFL) } \\
2 \text { (ELL) }\end{array}$ & 11 & 1 & - & 1 (No Information) \\
\hline 2 & 3 & 8 & $\begin{array}{c}2 \text { (TEFL) } \\
1 \text { (ELT) }\end{array}$ & 8 & 1 & 2 & $\begin{array}{c}2 \text { (M.A.-TEFL) } \\
1 \text { (CELTA holder) }\end{array}$ \\
\hline 3 & 4 & 5 & 2 (TEFL) & 7 & 1 & - & 1 (Ph.D.-TEFL) \\
\hline 4 & 5 & 12 & $\begin{array}{l}2 \text { (TEFL) } \\
2 \text { (ELL) }\end{array}$ & 13 & 1 & - & 1 (M.A.-TEFL) \\
\hline 5 & 3 & 9 & $\begin{array}{l}1 \text { (TEFL) } \\
1 \text { (ELL) }\end{array}$ & 10 & 1 & 1 & $\begin{array}{l}1 \text { (Ph.D.-TEFL) } \\
1 \text { (M.A.-TEFL) }\end{array}$ \\
\hline 6 & 3 & 5 & 1 (TEFL) & 7 & 1 & - & 1 (M.A.-ELL) \\
\hline 7 & 5 & 9 & $\begin{array}{c}3 \text { (TEFL) } \\
1 \text { (ELL) } \\
2 \text { (ELT) }\end{array}$ & 8 & 1 & 1 & 2 (CELTA holders) \\
\hline 8 & 3 & 6 & 2 (TEFL) & 7 & 1 & 1 & $\begin{array}{l}1 \text { (Ph.D.-TEFL) } \\
1 \text { (M.A.-TEFL) }\end{array}$ \\
\hline 9 & 3 & 7 & $\begin{array}{l}1 \text { (TEFL) } \\
1 \text { (ELL) }\end{array}$ & 8 & - & 1 & 1 (M.A.-TEFL) \\
\hline Total & 35 & 72 & $\begin{array}{c}18 \text { (TEFL) } \\
7 \text { (ELL) } \\
3 \text { (ELT) } \\
28 \text { English } \\
\text { Majors }\end{array}$ & 79 & 8 & 6 & $\begin{array}{c}3 \text { (Ph.D.-TEFL) } \\
6 \text { (M.A.-TEFL) } \\
1 \text { (M.A.-ELL) } \\
3 \text { (CELTA holders) } \\
1 \text { (No Information) } \\
14 \text { TTC Trainers }\end{array}$ \\
\hline
\end{tabular}

Notes: TEFL = Teaching English as a Foreign Language; ELL = English Language Literature; ELT = English Language Translation; CELTA = Certificate in English Language Teaching to Adults.

Fourteen TTC trainers consisting of six females (43\%) and eight males (57\%), ranging in age from 29 to 41, participated in the interviews. None of the trainers was a native speaker of English; three of them were Ph.D. candidates of TEFL (excluding one of the researchers who participated in all the nine courses to observe them); six of them were M.A. holders of TEFL, one of them held an M.A. in English Language Literature, three of them were not majoring in English, but held the Certificate in English Language Teaching to Adults (CELTA) qualification, and one of them was reluctant to provide the researcher with any information regarding his educational background. In addition, a questionnaire was administered to 107 TTC attendees. Of these, 35 were male $(33 \%)$ and 72 were female $(67 \%)$. The age distribution of the participants ranged from 19 to 35, and their average age was 22 years. Among the 107 preservice teachers who took the TTC's, 18 course attendees majored in TEFL, 7 in English Language Literature, and 3 in English Language Translation. Quite surprisingly, the other 79 trainees majored in other fields of study.

\subsection{Instrumentation}

In an attempt to collect quantitative data on course attendees' opinions on the effectiveness of the TTC's run in Iran, the questionnaire developed, piloted, and administered by Peacock (2009) was adapted and used. In Peacock's (2009) study, the internal consistency reliability of .87 was allotted to the items. Some minor modifications were made to the questionnaire to make it suitable for the context and purpose of the present study. Also, four items as well as two open-ended questions were added to the modified 
questionnaire (see Appendix 1) to gather more information on the inclusion of instruction on techniques pertaining to teaching all the four main language skills as well as DA in the TTC curricula. In crafting the added four items, the issue of content validity was taken into account by consulting the related literature prior to finalizing the wording and content of the items.

The TTC attendees $(N=107)$ gave their responses on a 5 -point Likert scale: strongly agree, agree, neither agree nor disagree, disagree, and strongly disagree. The Cronbach alpha internal consistency reliability of the entire sample of the present work was found to be .81 , and the questionnaire was piloted before administration. The TTC attendees were informed that their involvement in the study would not affect their final evaluation and that the questionnaires would be treated anonymously; so, it was compulsory for them to include their names as a part of demographic information.

\subsection{Procedures}

\subsubsection{Data Collection Procedures}

While observation and document analysis were used as the main means of data collection in the study, the employed data elicitation methods included carrying out an interview and administrating a questionnaire. Employing naturalistic inquiry (Best \& Kahn, 2006), the nine TTC's were carefully observed and their instructional practices and procedures were transcribed and field notes were made. One of the researchers was a participant during all observations in order to have a first-hand experience with participants. Since prolonged engagement can enhance research credibility (Mackey \& Gass, 2012, p. 194), the data were collected employing "participant observation" (Mackey \& Gass, 2012, p. 184). Given that "being a participant observer can give you a richer, insider perspective on the learning taking place ..." (Bartels, 2005b, p. 5), the observations were carried out by going into the field, that is, the real world of the TTC's. In order to address ethical issues, once the courses came to an end and when the observations were carried out permissions were obtained from the course organizers for using the gathered information as research evidence.

In qualitative interviews, the researcher conducted face-to-face semistructured, open-ended interviews with 14 trainers of the TTC's to elicit their opinions on the shortcomings and merits of the courses and seek their suggestions for further improvement on existing syllabi. The interviews which were done in English and took approximately 15 minutes involved four open-ended questions, crafted in the form of four items (see Appendix 2). The questionnaire, which took about 10-15 minutes to complete, was administered on the last day of each TTC, and 107 trainee teachers answered all of the items/questions.

\subsubsection{Data Recording Procedures}

Prior to the transcription of the observational data, an observational protocol, identifying the type of data, which was going to be recorded, and the procedures for recording the necessary data, was decided upon. To do so, informed by the research questions and the guidelines outlined by Creswell (2009), the researcher determined to take descriptive notes and gather demographic information and expound on the participants/actors of the observed sites, events, activities, and types and frequencies of instructional patterns with regard to the models of professional education in the descriptive notes. Also, an interview protocol was used for interviewing the TTC trainers. The collected data were recorded by making handwritten notes, and the interview protocol was piloted twice before commencing the real data collection.

\subsection{Data Analysis}

\subsubsection{Reliability and Validity Issues}

In order to check for qualitative reliability, also known as dependability, the researchers' approach was consistent across different sites (Gibbs, 2007; Creswell \& Miller, 2000), and the same strategies were adopted for recording the frequency of employment of each model of professional education and the transcription of instructional materials of all the observed sites. Important details of observed TTC's were noted in order to take care of the need for the documentation of details in qualitative research, which is 
referred to as thick description (Geertz, 1973; Yin, 2003). After the detailed documentation of the procedures of each TTC session, the model of professional education, the course curriculum, the inclusion of instruction on DA and on trainees' diagnostic competence in that very session were scrutinized by the researchers and cross-checked by a Ph.D. student of TEFL to ensure intercoder agreement (Miles \& Huberman, 1994). In other words, peer debriefing was used to enhance the accuracy of the accounts by letting people other than the researcher render a judgment on the analyses. The level of consistency of coding (i.e., inter-rater reliability index) was .93 and high enough to make the study reliable.

To ensure qualitative validity, also known as trustworthiness, authenticity, and credibility (Lincoln \& Guba, 2000), a number of validity strategies (Creswell, 2009) were incorporated into the analysis of the qualitative data. To start with, since credibility can be enhanced by triangulation of data, which is a kind of "discovery of commonalities" (Kimchi, Polivka, \& Stevenson, 1991, p. 364), the present study attempted to integrate views of different actors -TTC trainers and trainees- with the three raters' interpretations of the collected data. Therefore, different data source were triangulated to come up with united results and valid justifications. In other words, participant observation, questionnaire administration, and interviews were applied to data analysis procedures. Furthermore, not only was detailed, thick description of the activities and events used, but also member checking was utilized; that is, during the interviews, major research findings were taken back to course trainers so that they could attest to the authenticity of the findings. Last but not least, to address authenticity (Lincoln \& Guba, 2000), the data was analyzed without bias, open and honest descriptions of course contents were given, and the researcher refrained from reading more into the data than the data set could support.

\subsubsection{Analysis of the Collected Data}

The raters independently evaluated the transcribed descriptions of each TTC curriculum and calculated the frequency of employment of each model by determining the type of each and every instructional episode/act in the TTC's, classifying them under the three models of teacher learning, and recording the frequency of each classification. Moreover, the percentages of agreement/disagreement for all questionnaire items were calculated and the quantified data were classified under three categories: strongly agree or agree, neither agree nor disagree, and disagree or strongly disagree, for the ease of presentation and discussion. Next, the content of transcripts elicited by the semistructured interviews and open-ended questions of the questionnaire was analyzed, and blurbs quoting course trainers' opinions of course strengths and weaknesses were analyzed, and useful information was extracted from the comments to be further discussed and categorized.

\section{Results}

\subsection{Prevalent Models of Teacher Learning}

To answer the first research question, descriptive statistics were applied to delineate the frequency of models of professional education that could expound on methods of instruction adopted in the TTC's. Wallace's (1991) model of teacher learning served as a yardstick. Percentage distribution, as demonstrated in Table 2, indicates how many times strategies pertaining to each model was used in the instructional episodes of the TTC's.

Table 2. Percentages of the Employed Models of Teacher Learning in TTC's

\begin{tabular}{|l|l|l|l|}
\hline $\begin{array}{l}\text { Model of teacher } \\
\text { learning }\end{array}$ & The craft model & The applied science model & The reflective model \\
\hline Percentages & $84.73 \%$ & $11.42 \%$ & $3.85 \%$ \\
\hline
\end{tabular}




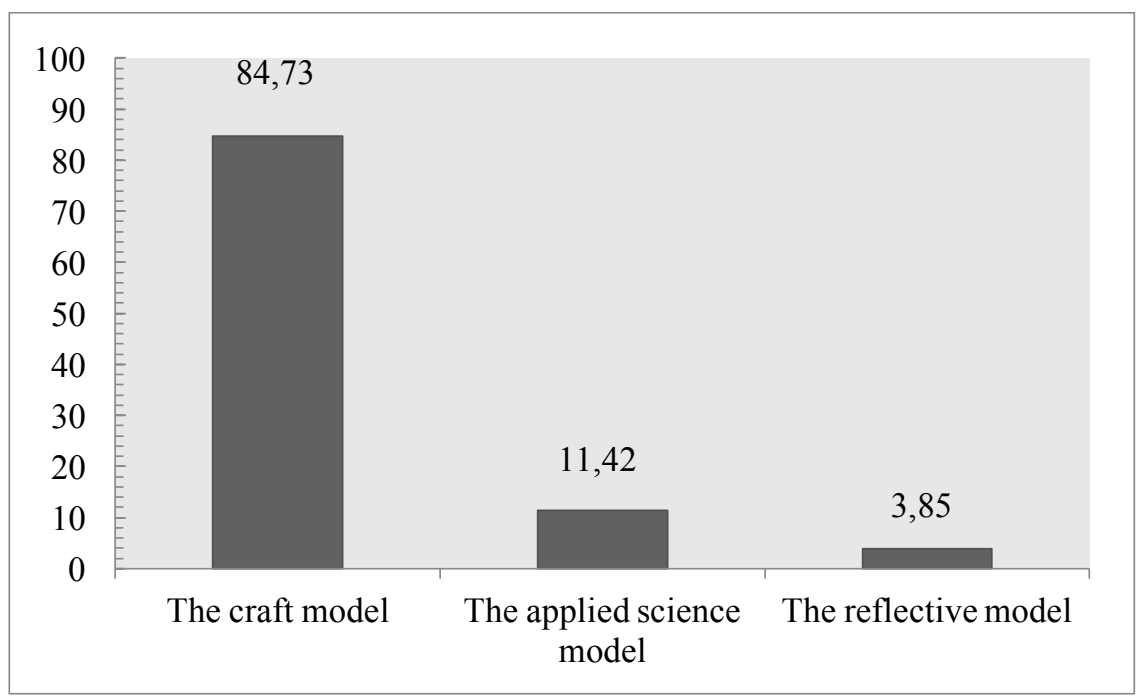

Figure 4. Frequencies of the three models of teacher learning in TTC's in percentage terms.

It was found that the craft model was the most frequently prevalent model of teacher learning in the TTC's. The low percentage of employing the applied science model shows that the primacy of being aware of theories and underlying assumptions of SLA, which can inform teachers' proactive approaches and pedagogical choices, was neglected. The reflective model was the least frequently prevalent model of teacher learning in the TTC's, which indicates that course organizers gave more weight to imitation rather than reflection.

\subsection{The Nine Observed TTC's}

In order to answer the second research question, the contents of the syllabi of the TTC's were examined with the aim of analyzing the time allotted and attention devoted to each language skill and other components of the course content and investigating whether recent empirical findings on classroom assessment, especially those of research into DA, were translated to the syllabi of the courses.

\subsubsection{Components of TTC Syllabi}

The written descriptions of the course syllabi, events and procedures of each TTC session were gathered and examined via participant observation. The course syllabi and observation notes were probed into in terms of (a) their model of professional education, (b) the attention devoted to each of the four language skills and other components/systems, (c) the balance between instructing attendees in teaching techniques and diagnostic competence, (d) the presence and quality of teachings on DA practices, and (e) the alignment of the teachings with recent research findings on classroom assessment practices. What follows is an account of the syllabi of the TTC's and clarification of possible ambiguities. Each session took three hours in the TTC's, except for sites 2, 5, and 7 in which each session took almost five hours; that is, each session was comprised of three instructional episodes each of which took an hour and a half. To observe ethics, the names of the nine observed sites are not included.

Table 3. Site 1: TTC Schedule

\begin{tabular}{cl}
\hline Session & Topics \\
\hline 1. & Icebreakers: getting to know the learners \\
\hline 2. & How to put learners in pairs / groups \\
\hline 3. & Classroom management: logistics, rapport, and teachers' language \\
\hline 4. & Monitoring learners: vanishing, active monitoring, discrete monitoring, and participating \\
\hline
\end{tabular}




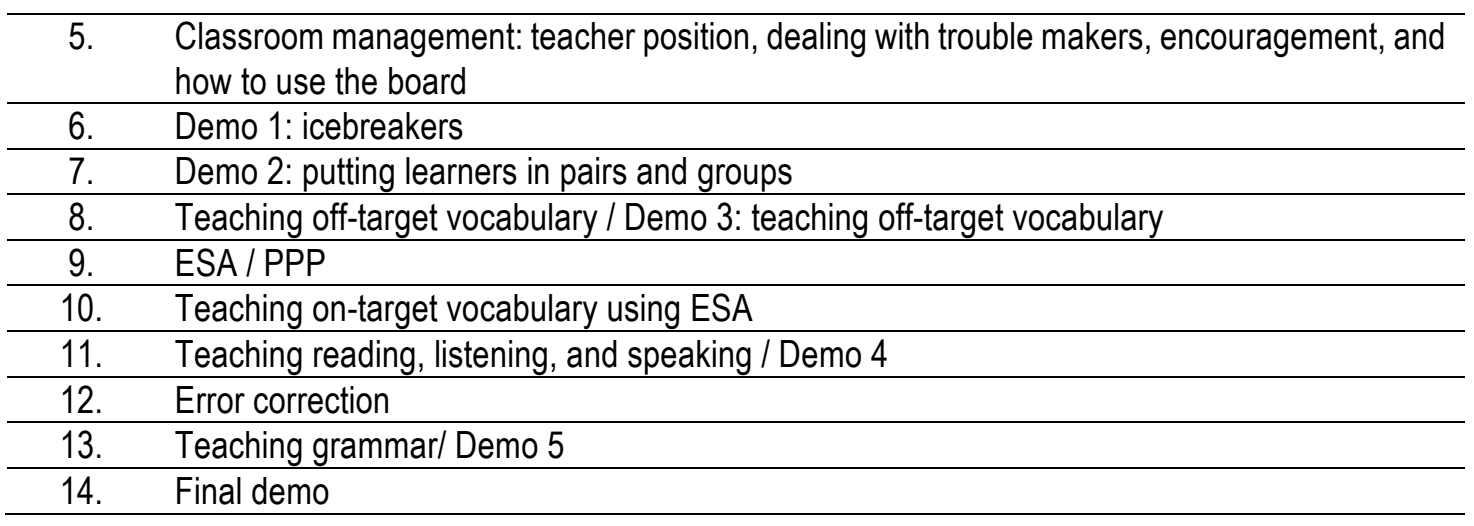

In this TTC, ESA stood for Engagement, Study, and Activation; the Study move included presentation and controlled practice. By PPP, Presentation, Practice, and Production was meant. As can be seen in the course program, writing skill was not attended to in this site and received a complete disregard. In session 12 , the differences between slips, errors, and attempts were discussed, but DA was neglected.

Table 4. Site 2: TTC Schedule

\begin{tabular}{cl}
\hline Session & Topics \\
\hline 1. & Introduction session: book orientation, learning styles, learner motivation \\
\hline 2. & Introductory session on 'Analytical Psychology' \\
\hline 3. & Classroom management / Lesson planning / Presenting vocabulary \\
\hline 4. & Developing receptive skills: listening and reading \\
\hline 5. & Discussing TPs / Observing experienced teachers \\
\hline 6. & TP 1: Receptive skills \\
\hline 7. & Presenting grammar / Practice new language \\
\hline 8. & Interaction patterns / Monitoring and feedback / Effective oral correction \\
\hline 9. & TP 2: Grammar \\
\hline 10. & Functional language \\
\hline 11. & Creativity and the teacher choosing and using supplementary materials \\
\hline 12. & TP 3: Function \\
\hline 13. & Developing productive skills: speaking and writing \\
\hline 14. & Teaching to teenagers \\
\hline 15. & Testing and assessment / Professional development \\
\hline 16. & Admin issues \\
\hline
\end{tabular}

As can be seen in Table 4, a part of session eight was devoted to teaching effective oral correction and feedback. In this session, ways of dealing with students' errors in speaking were discussed, but, in fact, different strategies of giving feedback were not attended to. However, in session 13, three strategies of correcting learners' writing samples were mentioned in passing: (a) the teacher can underline the mistakes; (b) the teacher can correct all the mistakes; and the teacher can assign codes and identify the mistakes. In the part of session 15 which dealt with testing and assessment, first, a 10-miute test was administered, and then achievement, diagnostic, placement, and proficiency tests were differentiated, but the trainers made no mention of DA. 
Table 5. Site 3: TTC Schedule

\begin{tabular}{cl}
\hline Session & Topics \\
\hline 1. & A general introduction to the course \\
\hline 2. & Presentations and expectations / Teaching vocabulary and grammar \\
\hline 3. & Topics, situations, notions, and functions / Receptive skills: listening and reading \\
\hline 4. & Productive skills: speaking and writing / Lesson planning and classroom management \\
\hline 5. & Interaction and corrective feedback \\
\hline 6. & Reflective teaching \\
\hline 7. & Evaluation and demonstration \\
\hline
\end{tabular}

In session two, for 'presentation and expectations', chapter four of Harmer's (2007) book was taught. As far as corrective feedback is concerned, the differences among mistakes/slips, errors, and attempts were enlarged upon, and the sources of errors (i.e., L1 interference, developmental errors, and induced errors mainly made by the teachers) were discussed. However, DA was neglected.

Table 6. Site 4: TTC Schedule

\begin{tabular}{cl}
\hline Session & Topics \\
\hline 1. & $\begin{array}{l}\text { Introduction of the course / Education vs. training / Post-method era / Learning cycle / } \\
\text { Teacher's role / EFL vs. ESL }\end{array}$ \\
\hline 2. & $\begin{array}{l}\text { Classroom management: giving instructions / ICQ / Interaction patterns / Using whiteboard / } \\
\text { Monitoring }\end{array}$ \\
\hline 3. & $\begin{array}{l}\text { Phonology: Single sounds, Word stress, Weak forms vs. strong forms, Stress timing, } \\
\text { Intonation, Connected speech }\end{array}$ \\
\hline 4. & Elicitation / Teaching vocabulary / CCQ \\
\hline 5. & Teaching grammar / PPP/ Error treatment / Demo \\
\hline 6. & BDA / Teaching listening / Teaching reading / Teaching writing / Teaching speaking \\
\hline 7. & Lesson planning / Reflective teaching / Work ethics /Demo \\
\hline 8. & TPs \\
\hline 9. & TPs \\
\hline
\end{tabular}

The most important role of a teacher, attended to in session one, was known to be creating a condition in which learning takes place. ICQ referred to Instruction Checking Question and CCQ to Concept Checking Question. In session five, which partly dealt with error treatment, self-correction, peer-correction, and teacher-correction were introduced, and a number of error identification strategies (e.g., facial expression, gesture, interjections, and echoing up to the error) were discussed. By BDA, Before/During/After was meant, which was similar to ESA.

Table 7. Site 5: TTC Schedule

\begin{tabular}{cl}
\hline Session & Topics \\
\hline 1. & Learner-centered teaching / Learner autonomy / Multiple intelligences \\
\hline 2. & Introduction to methodology / CLT \& TBLT \\
\hline 3. & Introduction to ESA / The course book \\
\hline 4. & How to teach grammar \& vocabulary + Workshop \\
\hline 5. & How to teach reading + Workshop \\
\hline 6. & How to teach listening + Workshop \\
\hline 7. & How to teach speaking + Workshop \\
\hline 8. & How to teach writing + Workshop \\
\hline 9. & Task management \& group dynamics + Workshop \\
\hline 10. & Lesson planning / Integration of skills in the course book \\
\hline 11. & Error correction / Feedback / Exams + Workshop \\
\hline 12. & Classroom management / Motivation \\
\hline 13. & Reflective teaching / Self-assessment / Written examination \\
\hline
\end{tabular}




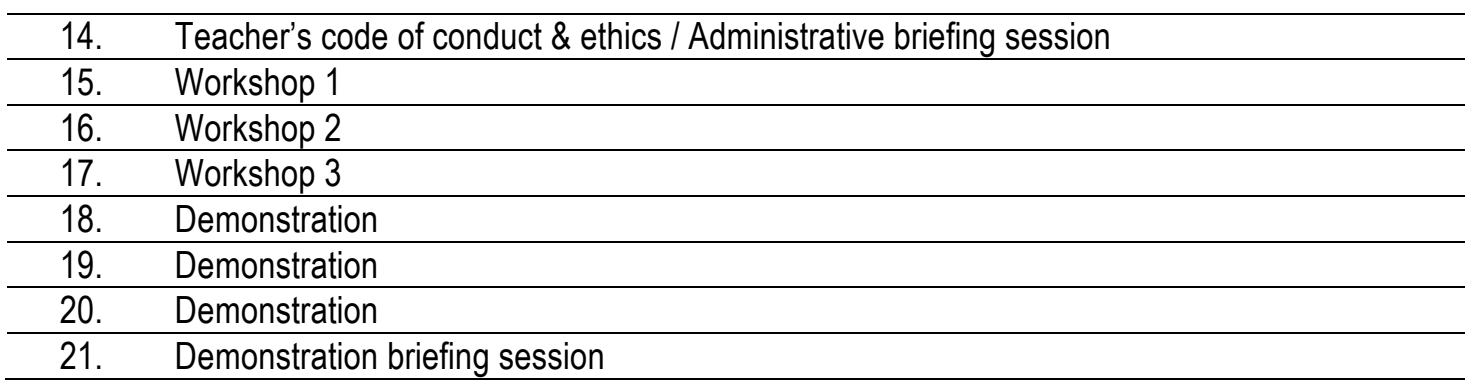

The three workshops dealt with phonology, classroom management, and orienting course attendees around administrative aspects and in-house issues of the institute. In session 11, a part of which dealt with feedback, no mention was made of DA.

Table 8. Site 6: TTC Schedule

\begin{tabular}{cl}
\hline Session & Topics \\
\hline 1. & An introduction to the course / Using course books \\
\hline 2. & Teaching: art or science / Describing good teachers \\
\hline 3. & Learner differences / Motivation and praise \\
\hline 4. & $\begin{array}{l}\text { Describing language: meaning in context and part of speech / teaching vocabulary / Using } \\
\text { the board }\end{array}$ \\
\hline 5. & Language form, function, and meaning / Teaching grammar \\
\hline 6. & Demo: teaching vocabulary and grammar \\
\hline 7. & Classroom management / Using the L1 / Student groupings / Monitoring \\
\hline 8. & Lesson stages: ESA / PPP / Activation of language \\
\hline 9. & Lesson planning: pre-task, task, and post-task / Demo \\
\hline 10. & Teaching reading / Demo \\
\hline 11. & Teaching writing / Writing steps / Correcting writing \\
\hline 12. & Teaching speaking / Correcting speaking / Demo \\
\hline 13. & Teaching listening / Types of listening / Demo \\
\hline 14. & When you start teaching: giving tests and scores \\
\hline 15. & TP \\
\hline 16. & TP \\
\hline
\end{tabular}

As far as feedback and error treatment is concerned, in session 11, overcorrection of writing samples was discussed, and attendees were advised to refrain from using red color and correcting all the mistakes, which can be very demotivating. It was suggested that they could attend to a certain aspect of students' writing at a time (e.g., grammar, spelling, punctuation, etc.) to minimize the amount of correction. In session 12 , immediate and delayed speaking correction was talked about. In the latter case, student teachers were advised to monitor learners, take notes on their mistakes, and talk about them once a task comes to an end without saying who had made the mistakes. In this site, classroom-based DA was taken for granted, and no instruction was given on possible ways of its implementation.

Table 9. Site 7: TTC Schedule

\begin{tabular}{cl}
\hline Session & Topics \\
\hline 1. & $\begin{array}{l}\text { Housewarming / Course introduction / Course book introduction / Planning stages of a lesson } \\
\text { / Reflection }\end{array}$ \\
\hline 2. & Managing learning (pair/group work) / Teaching approaches / Reflection \\
\hline 3. & Receptive skills: (reading \& listening) / Reflection \\
\hline 4. & Receptive skills mini TP / Reflection \\
\hline 5. & Productive skills: (speaking \& writing) / Assessment + Written correction / Reflection \\
\hline 6. & Grammar / Reflection \\
\hline 7. & Lexis/ Reflection \\
\hline 8. & Lexis and grammar mini TP/ Reflection \\
\hline
\end{tabular}




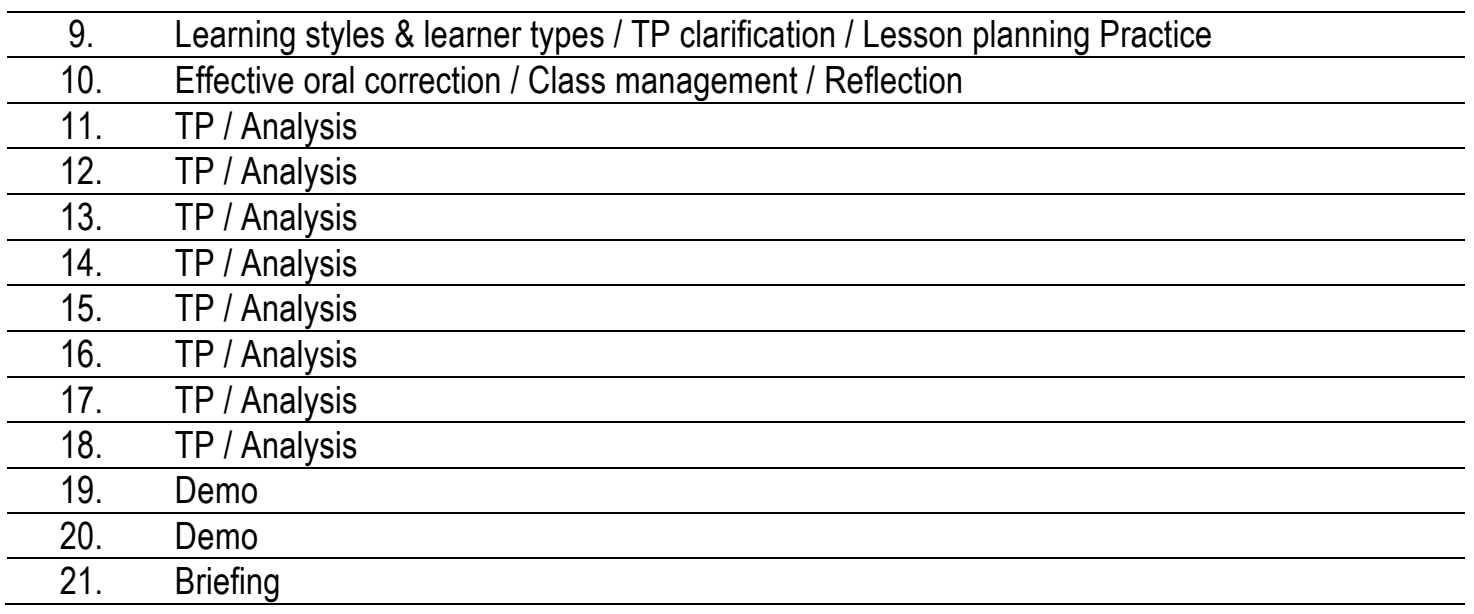

During TP's (i.e., Teacher Practice), trainee teachers were asked to teach a selected section (i.e., a microlesson) of a course book and tried to put what they had learnt regarding teaching the focused skill into practice. During the demos, which were regarded as a sort of end-of-course evaluation, trainee teachers taught a previously selected lesson in the presence of their peers and one or two evaluators, and they had to demonstrate their teaching and class management skills and abilities, acquired or improved throughout the TTC they had taken. The 'Reflections' at the end of the majority of the sessions had to do with course attendees' personal understanding of the teachings of that very session. During sessions five and ten, parts of which attended to assessment, written correction, and oral correction, preservice teachers were instructed on the techniques of providing learners with feedback on their writing and speaking skills; however, DA was not introduced to them.

Table 10. Site 8: TTC Schedule

\begin{tabular}{cl}
\hline Session & Topics \\
\hline 1. & Introduction: getting to know the participants / Why are you here? \\
\hline 2. & Who is a good language teacher? Teachers' characteristics and ethics \\
\hline 3. & $\begin{array}{l}\text { Getting to know the course book: levels and teaching method / Workbook and supplementary } \\
\text { materials }\end{array}$ \\
\hline 4. & Teaching listening and reading / Demo \\
\hline 5. & Teaching speaking and writing / Demo \\
\hline 6. & Giving feedback, midterm, and final scores: admin issues \\
\hline 7. & Teaching vocabulary and grammar / Demo \\
\hline 8. & Lesson planning: start to have your own lesson plans / Getting to know the course book guide \\
\hline 9 & / Assignment: write lesson plans \\
\hline 10. & Classroom management \\
\hline 11. & Demo / Assignment \\
\hline 12. & Final demo / Assignment demo / Assignment \\
\hline
\end{tabular}

The course organizers of site eight showed a complete disregard for the importance of classroom teacher assessment, and in session six, they only attended to possible strategies of giving feedback on their writing and speaking.

Table 11. Site 9: TTC Schedule

\begin{tabular}{cl}
\hline Session & Topics \\
\hline 1. & Background to language learning and teaching \\
\hline 2. & Language lexis \\
\hline 3. & Language grammar \\
\hline 4. & Language phonology \\
\hline
\end{tabular}




\begin{tabular}{cl}
\hline 5. & Language functions / Demo: teaching vocabulary and grammar \\
\hline 6. & Teaching receptive skills \\
\hline 7. & Teaching productive skills \\
\hline 8. & Teaching methods / Demo: teaching the main skills \\
\hline 9. & Giving instructions \\
\hline 10. & Error treatment / Giving feedback \\
\hline 11. & Demo \\
\hline 12. & Demo \\
\hline
\end{tabular}

In session ten, correcting students' written work was discussed, and preservice teachers were advised to factor in both the form and the content of what learners have written when they were given comments and feedback. Like the other eight observed sites, this TTC did not familiarize attendees with the principles of DA and classroom assessment practices either.

As far as the second research question is concerned, it can be noted that the TTC syllabi signified wide variations regarding the curricula among the courses; however, almost all observed TTC's had demonstrations in their curricula. In the TTC syllabi, 'microteaching' (i.e., a technique for advancing experiential knowledge of professional action in a progressive and controlled manner) was referred to as 'demo', 'demonstration', and 'TP'. In the related literature, considerable significance has been attached to the inclusion of microteaching (Crocker \& Dibbon, 2008; Falkenberg, 2010; Nuland, 2011; Wallace, 1991).

Although all TTC's except for site one, had instructions on the writing skill, writing skill, in general, was marginalized in all courses, and very little time and resources were allotted to effective ways of teaching and improving it. Similarly, trainers had a propensity for observing and evaluating preservice teachers' microteachings while they were working on speaking, reading, and/or listening skill, and the evaluation of teachers' ability to assess and enhance learners' writing ability was taken for granted. However, it is irrefutable that, at this juncture, writing skill is not of secondary importance and should not be a secondary consideration in the evaluation of teachers' professional practices. It is also worth noting that although, one way or another, the majority of TTC's attended to error correction and feedback, none of them included instruction on classroom assessment practices and DA in their syllabi, and TTC organizers demonstrated no regard for the development of prospective teachers' diagnostic competence.

\subsection{TTC Attendees' and Trainers' opinions About the Courses}

\subsubsection{Preservice Teacher Questionnaire}

In order to answer the third research question, agreement/disagreement percentages for each item were calculated. Results of the data are shown in percentage terms below in Table 12 and Figure 5.

Table 12. Preservice Teacher ( $N=107)$ Questionnaire Results

\begin{tabular}{|c|c|c|c|}
\hline The TTC ... & $\begin{array}{l}\text { Agree or } \\
\text { Strongly Agree } \\
(\%)\end{array}$ & $\begin{array}{l}\text { Neither Agree } \\
\text { Nor Disagree } \\
(\%)\end{array}$ & $\begin{array}{l}\text { Disagree or } \\
\text { Strongly } \\
\text { Disagree } \\
(\%)\end{array}$ \\
\hline $\begin{array}{l}\text { 1. ... had good linkage between } \\
\text { different teaching components. }\end{array}$ & 66.36 & 31.78 & 1.87 \\
\hline $\begin{array}{l}2 . \quad \ldots \quad \text { avoided overlapping information } \\
\text { between different teaching components. }\end{array}$ & 71.03 & 28.04 & 0.93 \\
\hline $\begin{array}{l}\text { 3. ... gave me adequate training in English } \\
\text { Language Teaching. }\end{array}$ & 71.96 & 26.17 & 1.87 \\
\hline $\begin{array}{l}\text { 4.... gave me adequate training in teaching all } \\
\text { the four skills. }\end{array}$ & 27.1 & 57.01 & 15.89 \\
\hline
\end{tabular}




\begin{tabular}{|c|c|c|c|}
\hline $\begin{array}{l}\text { 5. ... gave me adequate training for the needs } \\
\text { of the local context (teaching in English } \\
\text { institutes in Iran). }\end{array}$ & 73.83 & 24.3 & 1.87 \\
\hline 6. ... was up-to-date. & 66.36 & 32.71 & 0.93 \\
\hline $\begin{array}{l}\text { 7. ... taught me how to give feedback on my } \\
\text { students' writing. }\end{array}$ & 53.27 & 35.51 & 11.21 \\
\hline $\begin{array}{l}\text { 8. ... encouraged me to reflect on my past } \\
\text { experiences as a language learner. }\end{array}$ & 32.71 & 54.21 & 13.08 \\
\hline $\begin{array}{l}\text { 9.... encouraged me to be a reflective teacher } \\
\text { (when I start teaching). }\end{array}$ & 42.06 & 51.4 & 6.54 \\
\hline $\begin{array}{l}\text { 10. ... promoted flexibility in using different } \\
\text { teaching practices for different situations. }\end{array}$ & 43.93 & 49.53 & 6.54 \\
\hline $\begin{array}{l}\text { 11. ... balanced teacher-centered and } \\
\text { student-centered learning on its } \\
\text { teachings. }\end{array}$ & 63.55 & 32.71 & 3.74 \\
\hline $\begin{array}{l}\text { 12. ... taught me how to evaluate my students' } \\
\text { progress and abilities in writing. }\end{array}$ & 6.54 & 55.14 & 38.32 \\
\hline $\begin{array}{l}\text { 13. ... taught me how to help my students } \\
\text { develop their language abilities. }\end{array}$ & 19.63 & 48.6 & 31.78 \\
\hline $\begin{array}{l}\text { 14. ... taught me how to evaluate myself as a } \\
\text { teacher. }\end{array}$ & 31.78 & 46.73 & 21.5 \\
\hline $\begin{array}{l}\text { 15. ... taught me classroom management } \\
\text { skills. }\end{array}$ & 78.5 & 20.56 & 0.93 \\
\hline $\begin{array}{l}\text { 16. ... taught me how to use foreign language } \\
\text { teaching materials. }\end{array}$ & 70.09 & 25.23 & 4.67 \\
\hline $\begin{array}{l}\text { 17. ... taught me how to adapt foreign } \\
\text { language teaching materials. }\end{array}$ & 29.91 & 44.86 & 25.23 \\
\hline 18. ... increased my powers of self-evaluation. & 29.91 & 61.68 & 8.41 \\
\hline $\begin{array}{l}\text { 19. ... taught me foreign language } \\
\text { assessment skills. }\end{array}$ & 12.15 & 45.79 & 42.06 \\
\hline $\begin{array}{l}\text { 20. ... taught me how to integrate instruction } \\
\text { with assessment. }\end{array}$ & 9.35 & 45.79 & 44.86 \\
\hline $21 . .$. was relevant to my needs. & 71.96 & 26.17 & 1.87 \\
\hline $\begin{array}{l}\text { 22. ... had a good balance between the } \\
\text { teaching of: the main skills, language } \\
\text { assessment techniques, and classroom } \\
\text { management skills. }\end{array}$ & 45.79 & 42.99 & 11.21 \\
\hline $\begin{array}{l}\text { 23. ... prepared me to teach English in the } \\
\text { classroom. }\end{array}$ & 78.5 & 19.63 & 1.87 \\
\hline 24. ... met my needs. & 79.44 & 19.63 & 0.93 \\
\hline $\begin{array}{l}\text { 25. By the end of the TTC, I will be ready to } \\
\text { teach English. }\end{array}$ & 71.96 & 27.1 & 0.93 \\
\hline
\end{tabular}




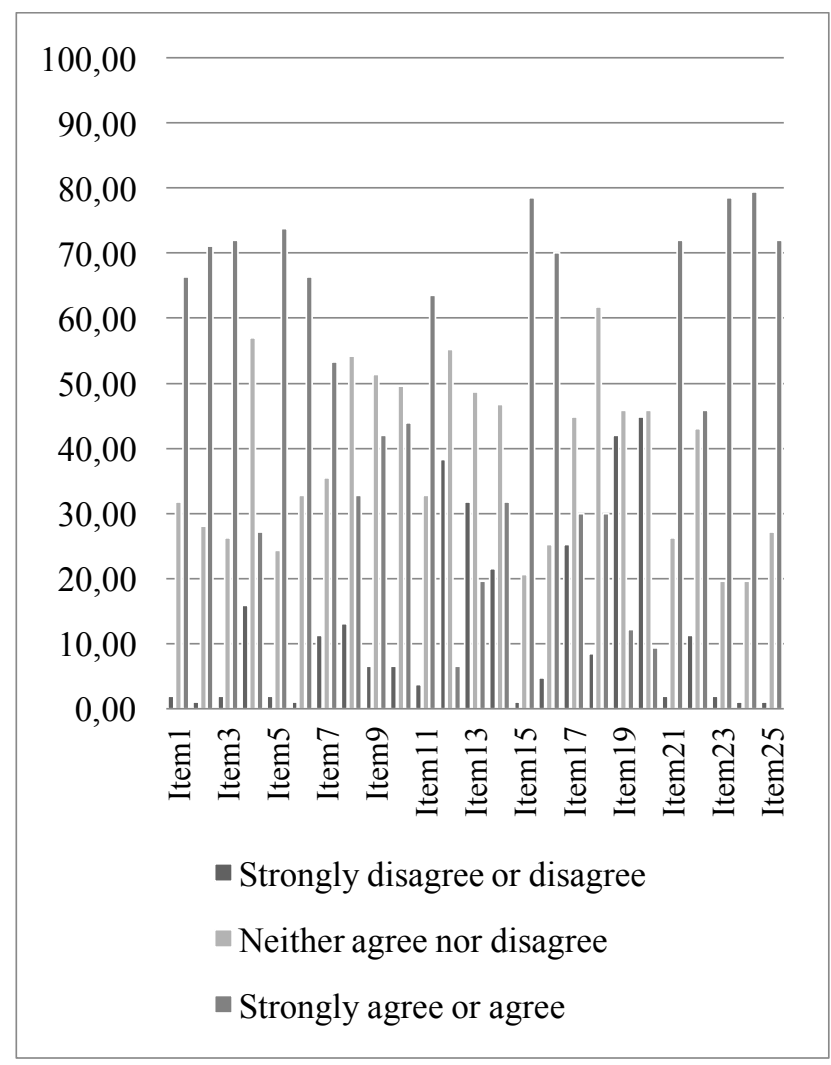

Figure 5. Preservice teachers' responses to the questionnaire depicted in percentages.

As can be seen in Table 12, items $24,15,23$, and 5 had the highest levels of preservice teacher agreement. $79.44 \%$ of preservice teachers agreed with 24 'The TTC met my needs', $78.5 \%$ with 15 and 23 'The TTC taught me classroom management skills' and 'The TTC prepared me to teach English in the classroom', and $73.83 \%$ with 5 'The TTC gave me adequate training for the needs of the local context (teaching in English institutes in Iran)'. Items 12, 20, 19, and 13 received the lowest levels of preservice teacher agreement. Only $6.54 \%$ of them agreed with 12 'The TTC taught me how to evaluate my students' progress and abilities in writing', 9.35\% with 20 'The TTC taught me how to integrate instruction with assessment', $12.15 \%$ with 19 'The TTC taught me foreign language assessment skills', and 19.63\% with 13 'The TTC taught me how to help my students develop their language abilities'.

Course attendees also responded to two open-ended questions in the questionnaire. Their answers to question 26 'Is there a specific language skill (listening, speaking, writing, or/and reading) on which you wish you had been provided with more instructions? Please elaborate on your answer' revealed that they felt a marked lack of instruction on teaching the writing skill and a relative lack of teachings on the speaking skill. In order to quote some relevant blurbs, pseudonyms are used. Mehdi wrote "I wish I would be more prepared for writing skill", Mina commented that "Writing is very difficult. I think I need more instructions for that skill and also for teaching function. I think it was better to have more examples and writing texts to practice", and Zhaleh made the point that:

For listening and reading we had a TP. So we got much more familiar with teaching these two skills and we experienced them in practice but not for writing and speaking. I wish we had a TP on speaking and writing too. I would like to get a hand on that.

Samples of attendees' answers to question 27 'What (positive/negative) comments can you make about the course you took?' are expounded on below. As far as TTC attendees' positive comments are concerned, the courses were known to be "fun", "practical", and "collaborative". Zahra wrote "The course was really useful and helpful", Reza held "I've been able to meet all my needs to be a teacher. Now I feel completely 
prepared to be a teacher and wholeheartedly want and yearn to do it", and Ali wrote "We had very good teamwork sessions. I learned a lot from them"; Amir commented that "It has given me the ability of teaching. Before that I had no single idea of a classroom, but now I can feel it. I know what to do".

Regarding the weaknesses of the TTC's, some course attendees believed that TTC's were too intensive and rushed. Fatemeh wrote "I liked to have more sessions and be more involved but generally it was a very fruitful course", and Saeed answered "We had very limited time to digest what we learned".

Although no explicit comment was made about the exclusion of classroom assessment from the course syllabi, two of the trainees alluded to this void by writing:

In the course I learned about teaching, but in the questionnaire there were questions about evaluating student abilities and adapting material which were not taught in the course. They said the exams are given to us. Do I need to know assessment and make tests?

And:

The whole course was an overall positive. Not able to count each and every, but one aspect of being a teacher was a little less respected, and that was assessment. I think it was a good idea to add a session on how to evaluate students on different skills and then find a suitable way to tackle their problems.

\subsubsection{Teacher Trainer Interviews}

In reporting the qualitative data gathered from the interviews, in order to observe ethics, the trainers will remain anonymous; so, pseudonyms are used instead of their real names. Regarding the strengths of the TTC's, some trainers $(N=6)$ said comprehensiveness was a merit. They held the course "was practical", "taught the maximum a teacher may need to learn in a minimized time", and "included the necessary teaching techniques". Several trainers $(N=9)$ said that the courses were goal-oriented and refrained from intangible, complicated theories that may not be used in the actual practice of teaching. Other trainers $(N=$ 5) said that the courses had microteachings, which attended to the practical aspects of teaching; Ehsan said "I believe my TTC's focus on performance alongside competence and let the candidates feel the content to the full".

Regarding TTC weaknesses, two $(N=2)$ trainers said they wished they had been able to hold different courses for teachers who were preparing to teach children, teenagers, and adults. Five $(N=5)$ instructors said that they wished they had had more attendees in their courses, so that they could assign more collaborative assignments and tasks.

Regarding possible ways of improving the TTC's, Saeed said "at least two or three trainers must run the course", and he maintained that it would be a good idea to have a number of "natural learners" in the TTC. Neda said "It is good to go to a real class with the trainees and see what happens", and, finally, Amir said "I think it is a good idea to ask participants to observe some classes and report on them".

As far as the alignment of research findings with the TTC syllabi is concerned, a number of interviewees $(N=5)$ believed that current constraints regarding access, time, and payments were major challenges of referring to research for improving TTC's. Some trainers $(N=8)$ did not even know where they could find relevant articles or reports. Reza said "We do not have access to good articles, and if we have, we do not have that much time to read all of them. To be honest, we are not paid to read articles; we are paid to have teacher-training courses".

Some trainers stated that second language acquisition papers and publications are full of convoluted terms and sentences, and, at times, they are so complicated that the reader gets bewildered. A number of them $(N=5)$ stated that intricately presented data analysis and statistics can be very unappealing and even demotivating, because they can barely make any sense of them. Saeed asserted that "Even if we bother to find and read relevant articles, we cannot easily figure out what suggestions are made in them. Many authors beat about the bush and discuss many issues, and many articles are not easy to follow". 
Some TTC organizers $(N=4)$ set out that generalizations made in research articles do not correspond to their local teaching context. A number of them $(N=2)$ held that the Iranian EFL context has distinguishing characteristics, which are not taken into account in the majority of research articles. Some trainers $(N=5)$ were quite complacent about the status quo of the TTC's. Three of the trainers $(N=3)$ did not feel responsible for bridging the gap between research and pedagogy, and they held teachers and course book writers responsible in this regard; fir instance, Payman said:

In our institute, we believe that teachers' guide of the course books we use are very important. They give the teachers the necessary and sufficient information about teaching each lesson and episode of the book. We also change our course books every four or five years to make them upto-date. This is what we can do. Let's say this is all we can do. Course book writers and those who write teachers' guides must put the necessary details and new findings in their books, because teachers can follow what they put in the guides.

\section{Discussion and conclusions}

\subsection{Models of Teacher Learning in TTC's Held in the Iranian EFL Context}

Results of the present study indicated that accounting for $84.73 \%$ of teacher-training instructional attempts, the prevailing model of teacher learning dominating TTC's in language institutes in Iran was the craft model of professional education, which looks at teaching as a craft that is comprised of certain predetermined technical skills and can be taught to the novice, who are mainly engaged with what steps to follow rather than why to take each measure. Put another way, trainees seemed to be absolved of all responsibility for figuring out why they took certain steps in their actual teaching practices throughout the courses (i.e., microteachings). This lens frames TE as a process whose goal is to deal with teachers' instrumental capabilities, mainly because the craft model is imitative in nature and mainly applies to static professions but not dynamic ones, which are geared to change.

Although learning technical skills of teaching, teaching routines, and codified stages of teaching certain instructional content has its own merits, the craft model or teacher-craft TE (Zeichner, 1983) neglects the fact that in teaching, like any other complex activity, "the whole is more than the sum of the parts" (Zeichner, 1983, p. 5), and "rule structures are inexhaustive" (Scheffler as cited in Tom, 1980, p. 318). That is, the immediate teaching context and teachers' tacit knowledge are of significant importance in the practice of effective teaching. In addition, pedagogy, directly or otherwise, affects ethical, moral, social, and political issues, and if teachers are merely taught how to teach with monotonous regularity, their reflective capabilities will be scaled down. It is important to note that a teacher's sense of plausibility, as Prabhu (1990) argues, determines how learning occurs and how teaching causes or supports learning, and L2 teachers are "users and creators of legitimate forms of knowledge who make decisions about how best to teach their $L 2$ students within complex socially, culturally, and historically situated contexts" (Johnson, 2006, p. 239).

While the applied science model is believed to be "the most prevalent model underlying most training or education programmes for the professions" (Wallace, 1991, p. 8), results of the study also showed that the applied science model accounted for only $11.42 \%$ of total teacher-training moves in the TTC's. Finally, the least frequently employed model of teacher learning in the TTC's was the reflective model, which accounted for only $3.85 \%$ of total instructional attempts made in the nine observed courses. It can be discussed that ease of administration and unthinking tradition may have led to the existing models and modes of teaching and learning in TTC's held in Iran.

\subsection{Curricula of the TTC's}

The analysis of the TTC syllabi denoted that there was no integrated national system of EFL teachertraining and significant differences in course delivery, duration, regulations, curricula, and end-of-course assessment was noted. Grosse's (1991) study concluded that this very problem also lied with TESOL methods 
course. The markedly different TTC's would exert various influences on preservice teachers' learning experiences and their professional expertise. The same concern was addressed by Nuland (2011) who made the point that "teacher education programmes within Canada are markedly different in structure and duration across provinces, which affects programme delivery for teacher candidates and their opportunities for clinical practice" (p. 409).

Results of the present study pertaining to absence of instruction on assessment in preservice TTC's are in line with the contention that "the dichotomy between assessment and instruction is even visible at the level of instructional organization" (Poehner, 2008, p. 4). The current status of the TTC's held in Iran calls for the inclusion of instruction on how to implement DA in TTC's because for a TTC design to be effective and sustainable, direct relevance of course contents to teachers' work and students' needs must be taken into account, and course curricula must lend themselves to helping teachers put theory into practice (Yuen-kwan, 1998). Also, according to Johnson (2009), the knowledge base of $L 2$ teacher education is, by definition, "the basis upon which we make decisions about how to prepare L2 teachers to do the work of this profession" ( $p$. 21). Moreover, input on SLA can "change teachers' intentions of how they will teach" (Bartels, 2005a, p. 406). Therefore, not only courses on applied linguistics and SLA are regarded as an important part of teachers' professional development (Edwards \& Owen, 2005; Grabe, Stoller, \& Tardy, 2000), but also it is held that teachers would make use of the knowledge gained from the courses in their teaching practices (Bartels, 2005a; Popko, 2005). Doubtless, the revamp of pedagogical orientations to DA requires "further collaborative endeavors between practitioners and researchers" (Ishihara, 2010, p. 947).

\subsection{TTC's from Attendees' Perspective}

In line with findings of the participant observation, preservice teacher questionnaire results and comments indicated that the TTC's did not do well in instructing the attendees to teach the writing skill and implementing classroom assessment practices and DA. The lowest levels of preservice teacher agreement were with questionnaire items $12,20,19,13$, and $4(6.54 \%, 9.35 \%, 12.15 \%, 19.63 \%, \& 27.1 \%$ respectively) and their answers to questions 26 and 27 backed this contention up. Among these five items, items 12 and 4 pertain to writing and items 20,19, and 13 to DA. However, questionnaire results indicated that the courses successfully met attendees' needs (item 24), were relevant to their needs (item 21), gave them adequate training for the needs of the local context (item 5), and prepared them to teach English in the classroom (item 23). Also, the courses appeared to be successful in teaching classroom management skills (item 15). Trainer interview comments and attendees' responses to the open-ended questions backed up these findings.

\subsection{TTC's from Trainers' Perspective: Factors Influencing the Current Research-Practice Divide}

The data collected through interviews with TTC trainers as well as field notes of participant observations and the relationships among them were used to identify recurring categories and concepts regarding the factors that hamper empirical research findings finding their way into the instructional materials of TTC's. Open, selective, and axial coding and content analyses of the collected data gave rise to a sum of eight themes (see Figure 6.), which are enlarged upon below.

\subsubsection{Perceived Gap Between Research/Researchers and Pedagogy/Teachers}

The mismatch between theories driven from SLA research and classroom language teaching practices has been touched on by several scholars (Firth \& Wanger, 1998; Katz \& Watzinger-Tharp, 2005; Ortega, 2005). Moreover, it is believed that "the gap between educational research and practice will not narrow without significant changes in pre- and in-service teacher educational programs" (Ben-Peretz, 1994, p. 116). Findings of the present study, similarly, revealed a lack of connection between research and TTC instruction and curricula, which can lead to a split between research and professional practice in language pedagogy and lack of compatibility between SLA research and classroom practice.

One way to bridge the theory-practice divided in language pedagogy can be familiarizing pre and in-service teachers with recent findings of SLA research, providing them with practical guidelines on the implementation of empirical findings in classroom context, availing them of opportunities for guided practice, and monitoring 
them with the aim of improving their performance and fostering self-reflection. This can be a promising endeavor because "language teaching is largely propelled by the discourse of methodology, which is expressed in terms of classroom practice, theories, and ideologies of learning" (Freeman, 2007, p. 903). In addition, active involvement of major stakeholders in educational contexts would help "blend top-down initiatives and bottom-up participation" (Ben-Peretz, 1994, p. 114).

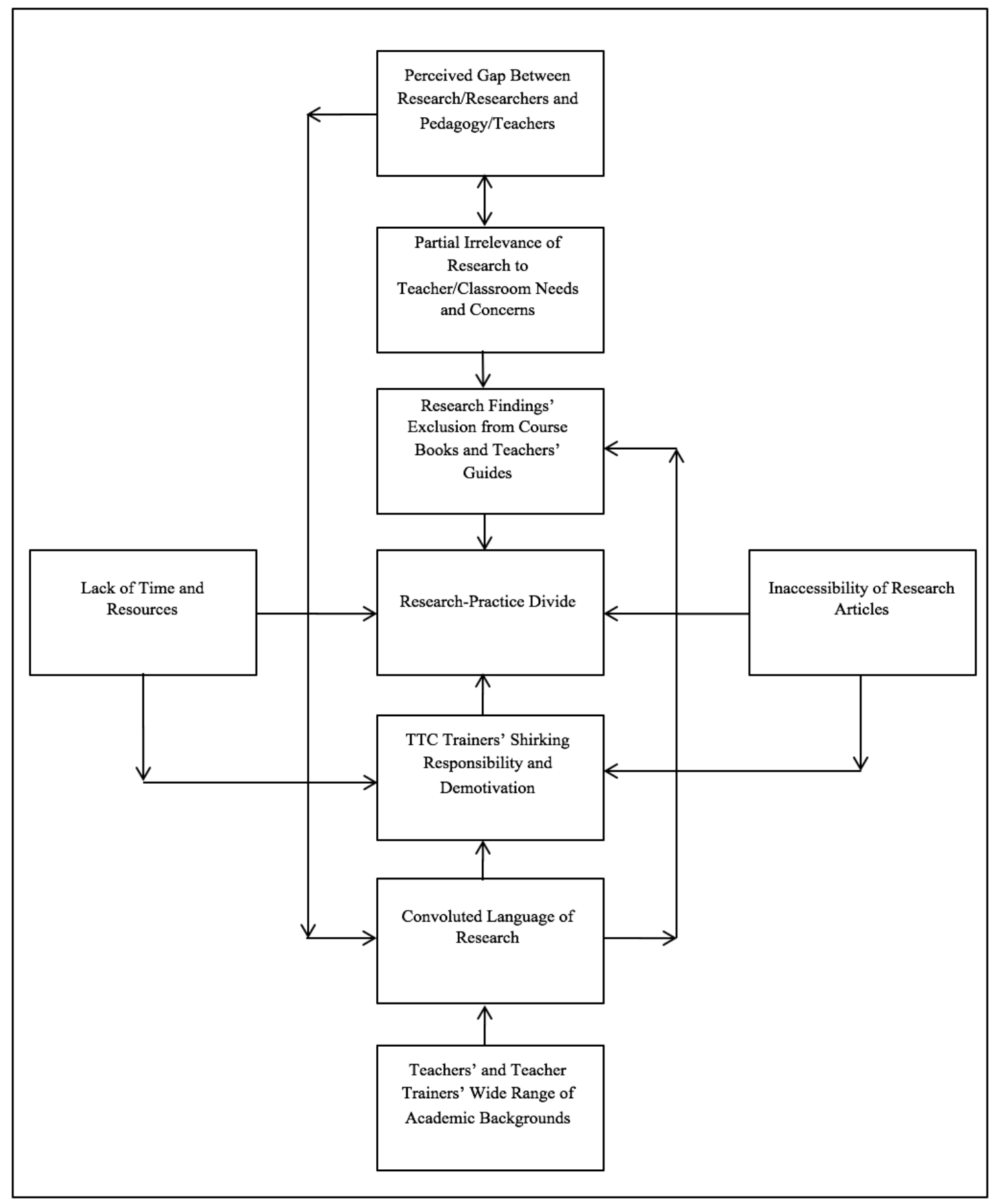

Figure 6. Factors influencing the current research-practice divide in TTC's. 


\subsubsection{Partial Irrelevance of Research to Teacher/Classroom Needs and Concerns}

Results of the interviews showed that some TTC trainers believed that many research reports do not attend to concerns pertaining to actual classroom contexts. In the related literature, it is believed that applied research is not merely after more applications of the same theory and the relationship between theory and practice is not one-way, that is, theory provides grounds to guide pedagogical activity, and, practical activity, simultaneously, develops and informs theory (see Lantolf \& Poehner, 2010), which is also referred to as 'praxis' (Vygotsky, 1997). Moreover, according to Tierney (2006), bringing about change in classroom assessment practices calls for sustained, cooperative, and joint effort of knowledge generating source (i.e., researches) and internal and external mediating sources (e.g., educational policy-makers, language program organizers, teacher trainers/educators, teachers, etc.). Bearing in mind the fact that modes of research should be wellsuited to the needs of teachers (Ben-peretz, 1994), researchers are to enunciate the implications of their studies for practitioners and materials developers, and teachers are to put empirical findings into practice and feed researchers with their reflections and first-hand experiences.

Moreover, as long as teachers perceive the relationship between themselves and researches as opposing, "there is little chance that university-generated knowledge might become part of the developing knowledge base of practitioners" (Ben-Peretz, 1994). So, to narrow the unchecked gap between researchers and practitioners, it must be noted that teachers' experience, perception, and concerns, informed by their teaching practices in the real, complex context of classrooms can offer avenues towards new research topics and themes based on the needs and concerns of actual classes.

\subsubsection{Research Findings' Exclusion from Course Books and Teachers' Guides}

One of the TTC trainers pointed out that in the institute in which he worked, course books were up-dated every four or five years, and he noted that this was done to ensure that new teaching innovations and practices find their way into practice. What he said alluded to the primacy of the role of materials developers and curriculum designers in SLA. They are expected to pay proper regard for the implications of recent empirical research findings for pedagogy by including them in the form of practical guidelines in the materials they develop, including teachers' guides. Tomlinson (2011) posited that collaboration is one of the key components of materials development principles and procedures. He reiterated the value of pooling resources and purported that teachers, curriculum developers, university lecturers, researchers, teacher trainers, textbook writers, and publishers are the main contributors in a collaborative endeavor of materials development.

\subsubsection{Teachers' and Teacher Trainers' Wide Range of Academic Backgrounds}

Findings of the present study (see Table 1) revealed that a large majority of TTC attendees and some of the TTC trainers did not major in fields of study related to English and had no academic background in language teaching, which is a threat to professionalism in the field. Given that one of the roles a language teacher assumes is the role of a user (Edge, 1988; Wright, 2002), who consults scientific resources to solve classroom problems, it is unlikely that preservice or in-service teachers who come from educational backgrounds other than language teaching would be able to refer to academic language textbooks, research articles, and reference books.

Allowing candidates from diverse educational backgrounds to enter TTC's and become language teachers neglects the fact that "technical skill in teaching is to be highly valued not as the end in itself, but as a means for bringing about desired needs" (Zeichner, 1983, p. 6). Put another way, teachers who are not familiar with the scientific and theoretical fundamentals of language teaching might become efficient teachers by acquiring technical skills of teaching and gaining practical experience; however, their becoming action researchers and/or inquirers seems to be improbable.

\subsubsection{Convoluted Language of Research}

Given that a number of TTC trainers believed that the language of research findings are often perplexing and abstruse, they adopt elaborate study designs, and they tend to report recondite facts and figures that 
cannot be easily understood by practitioners, researchers are advised to turn the implication section of research report genre to good account, clearly communicate to their target audience, and state how new insights generated by their research can be used in practice by providing clear, practical implications and guidelines. As Elliot (2000) put it, educational psychologists must ensure that they translate their findings into a readerand curriculum-friendly format.

\subsubsection{TTC Trainers' Shirking Responsibility and Demotivation}

It is worth mentioning that teacher trainers are also expected to be motivated to stay abreast of the latest developments in the field; they cannot afford to be complacent about their teaching practices and curricula, for they can do much to stimulate the sustained use of research findings. Doubtless, teachers' professional communities and learning communities of teachers can feed into the enhancement of teacher collaboration in this regard (McLaughlin \& Talbert, 1993; Rosenholtz, 1989). Being a member of such communities would encourage teachers and teacher trainers to actively engage in the analysis and evaluation of research-based findings, and they can put them to regular use in their common pursuits.

Teacher trainers must be aware of the significance of their professional responsibilities as well as their important role in language pedagogy, which can be motivating. Since through TTC's, preservice teachers acquire insights into the practice of teaching, teacher trainers should bear in mind that such courses can join the efforts of scholars and practitioners by instructing prospective teachers and informing them about ways trough which they can deal sensibly with innovative pedagogical approaches based on research.

\subsubsection{Inaccessibility of Research Articles}

Results of the interviews indicated that gaining access to relevant research findings and literature on second language teaching and learning, which is demotivating for trainers, was a key issue to be dealt with. Language institute administrators can provide teachers and teacher trainers with some facilities to search the required resources on reliable databases.

\subsubsection{Lack of Time and Resources}

The amount of time and the resources allocated to TTC's and teacher trainers are among the important contextual factors that can affect TTC structure and function by influencing how such courses are implemented and maintained as well as trainers' level of motivation. Shortage of time imposes constrains on administrators of TTC's. Moreover, busy schedules leave little room, if any, for change in the planning of TTC's. Therefore, "twin demons of time and pace" (Schulman, as cited in Ben-Peretz, 1994) affect the context of institutions, and, consequently, making conscious attempt to read and use relevant research findings pales into significance beside other priorities such as following curricula on schedule. To lower the barriers created by the lack of budget and time, institutes can allocate a fixed budget to their training departments, just like R \& D (research $\&$ development) departments of businesses, which are concerned with studying new ideas and draw up plans for the production of new products. In fact, the primacy of the power of institutional practice and institutional customs in leaving little room for change has already been emphasized in the literature (Ben-Peretz, 1994; Fullan, 2007; Sarason \& Doris, 1979).

\subsection{Implications and Suggestions for Further Research}

Given that it is important to systematically evaluate language teacher-training/preparation courses (Lynch, 2003; Peacock, 2009; Rea-Dickins \& Germaine, 1998), findings of the present study can provide an opportunity to scrutinize the employed models of professional education in preservice TTC's held in the Iranian EFL context, the extent to which ZPD-based assessment (Van Compernolle \& Kinginger, 2013, p. 299) is dealt with in such courses, and the strengths and weaknesses of them.

As to the models of teacher-learning in TTC's, it should be borne in mind that although the craft model has certain advantages in training prospective English teachers, TTC trainers should not lose sight of the fact that 
for instruction to produce optimal learning benefits, preservice teachers are to systematically ponder and analyze what they have learnt through reflection. So, findings of the study put forward arguments for the need for creating new pathways to prepare English language teachers in the Iranian EFL context to improve the teaching and professional qualifications of prospective teachers.

Moreover, marking down the curricula of the observed TTC's illuminated and typified the potential axioms that were regarded as substantive matters and/or ancillary issues by TTC organizers. Another cornerstone of the findings, which brought the status quo of the TTC's to further light, was that they flagged the complete disregard for classroom assessment practices, DA, and teachers' roles as mediators in TTC's. The fact that instruction in the aforementioned issues was conspicuously absent from TTC syllabi signifies that TTC organizers might have felt that their inclusion was surplus to requirement; however, this study discussed that such issues are hailed as pivotal matters in the relevant, existing literature. Also, the findings can orientate the stakeholders towards the premise that pedagogy must keep pace with research, and the tenuous link between research and pedagogy must be alleviated. In order to make a contribution to the revival of the status quo of the TTC's, the preset study also attended to the reasons that call a halt to the inclusion of relevant recent research findings in the instructional materials of TTC's. Doubtless, meeting the challenges can ameliorate the present status of the courses.

To sum up, based on the findings of the study, recommendations pertaining to educational policies, practice, and research can be made. Policy makers should be informed of the benefits of the application and alignment of research findings to and with the teachings of TTC's. Stakeholders must acknowledge that the aim of research in SLA is improving language pedagogy, and if they simply get into a routine in exercising their professional responsibility, the bifurcation between research and professional practice would widen.

As far as practice is concerned, as Kozulin (2009) notes, classroom context is a promising vein for the implementation of DA. However, it seems that classroom-based DA has yet to break into mainstream educational practice, and instructing pre-and in-service teachers to apply the principles of DA in their classroom can be a starting point for implementing DA.. It is high time teacher educators pondered on what forms the basis of their teacher-training curricula, and they must consider how their instruction shapes prospective teachers' worldview towards their profession. Language teachers should bear in mind that for teaching to be effective, not only should links between assessment and classroom practice be made (Lidz, 1991), but also results of each stage of assessment must feed into their subsequent interventional moves. This cannot be achieved unless teacher trainers and language teachers gain a clear understanding of DA and its practical application guidelines. Materials developers and syllabus designers are to be sensitized to the beneficial effects of DA in learner development and leave room for DA practices in the pedagogical materials they develop.

Further studies can look into the role that using technology might play in TTC's. Given that the appropriate use of technology can help teachers effectively deliver instruction to students and motivate them, familiarizing student-teachers with the underpinning assumptions of computer-assisted language learning (CALL) and barriers to using technology in TTC's requires further study. In this line of research, the gap between theory and practice can be examined, too. Moreover, within this strand of research, future studies could explore the inclusion of other empirically approved classroom techniques in the course curricula. For instance, the inclusion of teachings on learner-tailored feedback and the implementation of Group DA (G-DA) could give venue for new research projects.

\section{References}

Abednia, A. (2012). Teachers' professional identity: Contributions of a critical EFL teacher education course in Iran. Teaching and Teacher Education, 28, 706-717.

Ableeva, R., \& Lantolf, J. (2011). Mediated dialogue and the microgenesis of second language listening comprehension. Assessment in Education: Principles, Policy \& Practice, 18(2), 133-149.

Albirini, A. (2006). Teachers' attitudes toward information and communication technologies: The case of Syrian EFL teachers. Computers and Education, 47, 373-398. 
Aljaafreh, A., \& Lantolf, J. P. (1994). Negative feedback as regulation and second language learning in the zone of proximal development. The Modern Language Journal, 78, 465-483.

Allal, L., \& Pelgrims Ducrey, G. (2000). Assessment of-or in-the zone of proximal development. Learning and Instruction, 10, 137-152.

Bartels, N. (2005a). Applied linguistics and language teacher education: What we know. In N. Bartels (Ed.), Applied linguistics and language teacher education. New York: Springer. pp. 405-424.

Bartels, N. (2005b). Researching applied linguistics in language teacher education. In N. Bartels (Ed.), Applied linguistics and language teacher education. New York: Springer. pp. 1-26.

Bartels, N. (2009). Knowledge about language. In A. Burns \& J. C. Richards (Eds.), The Cambridge guide to second language teacher education. Cambridge: Cambridge University Press. pp. 125-134.

Ben-Peretz, M. (1994). The dissemination and use of research knowledge in teacher education programs: A nonevent? Knowledge and Policy, 7(4), 108-117.

Berrill, D., P., \& Addison, E. (2010). Repertoires of practice: Re-framing teaching portfolios. Teaching and Teacher Education, 26, 1178-1185. doi: 10.1016/j.tate.2010.02.005

Best, J. W., \& Kahn, J. (2006). Research in education (10th ed.). Boston: Pearson Education Inc.

Borg, S. (2003). Teacher cognition in language teaching: A review of research on what language teachers think, know, believe and do. Language Teaching, 36, 81-109.

Borg, S. (2006). The distinctive characteristics of foreign language teachers. Language Teaching Research, 10(1), 3-31.

Brownell, M. T., Griffin, C., Leko, M. M., \& Stephens, J. (2011). Improving collaborative teacher education research: Creating tighter linkages. Teacher Education and Special Education, 34(3), 235-249.

Burton, J. (2009). Reflective practice. In A. Burns \& J. C. Richards (Eds.), The Cambridge guide to second language teacher education. Cambridge: Cambridge University Press. pp. 298-307

Celce-Murcia, M. A. (2001). Teaching English as a second or foreign language (3rd ed.). USA: Heinle \& Heinle.

Chacon, C. T. (2005). Teachers' perceived efficacy among English as a foreign language teachers in middle schools in Venezuela. Teaching and Teacher Education, 21, 257-272.

Clark, C. M., \& Peterson, P. L. (1986). Teachers' thought process. In M. C. Wittrock (Ed.), Handbook of research on teaching (pp. 255-269). New York: Macmillan.

Clarke, M. (2004). Reflection: Journals and reflective questions: A strategy for professional learning. Australian Journal of Teacher Education, 29(2), 11-23.

Creswell, J. W. (2009). Research design: Qualitative, quantitative, and mixed methods approaches (3rd ed.). Los Angeles: Sage.

Creswell, J. W., \& Miller, D. (2000). Determining validity in qualitative inquiry. Theory Into Practice, 39(3), 124130.

Crocker, B., \& Dibbon, D. (2008). Teacher education in Canada. Kelowna: Society for the Advancement of Excellence in Education.

Delaney, Y. A. (2012). Research on mentoring language teachers: Its role in language education. Foreign Language Annals, 45(1), 184-202.

Dorfler, T., Golke, S., \& Artelt, C. (2009). Dynamic assessment and its potential for the assessment of reading competence. Studies in Educational Evaluation, 35, 77-82.

Edelenbos, P., \& Kubanek-German, A. (2004). Teacher assessment: The concept of 'diagnostic competence'. Language Testing, 21(3), 259-283. doi: 10.1191/0265532204lt284oa

Edge, J. (1988). Applying linguistics in English language teacher training for speakers of other languages. ELT Journal, 42(1), 9-13. 
Edwards, C., \& Owen, C. (2005). The impact of teachers of language variation as a course component. In N. Bartels (Ed.), Applied linguistics and language teacher education. New York: Springer. pp. 43-58.

Elliott, J. (2000). Dynamic Assessment in educational context: Purpose and promise. In C. Lidz \& J. Elliott (Eds.), Dynamic Assessment: Prevailing models and applications. New York: Elsevier. pp. 713-740

Ellis, R. (2010). Second language acquisition, teacher education and language pedagogy. Language Teaching 43(2), 182-201.

Ellis, R. (2013). Corrective feedback in teacher guides and SLA. Iranian Journal of Language Teaching Research 1(3), 1-18.

Falkenberg, T. (2010). Introduction: Central issues of field experiences in Canadian teacher education programs. In T. Falkenberg \& H. Smits (Eds.), Field experiences in the context of reform of Canadian teacher education programs, Vol. 1. Winnipeg, MB: Faculty of Education of the University of Manitoba. pp. 1-50

Fanselow, J. F. (1997). Beyond rashomon: Conceptualizing and describing the teaching act. TESOL Quarterly, 11(1), 17-39.

Firth, A., \& Wagner, J. (1998). SLA property: No trespassing. Modern Language Journal, 82, 90-94.

Flores, M. A., \& Day, C. (2006). Contexts which shape and reshape new teachers' identities: A multiperspective study. Teaching and Teacher Education, 22(2), 219-232.

Freeman, D. (1982). Observing teachers: Three approaches to in-service training and development. TESOL Quarterly, 16(1), 21-28.

Freeman, D. (2002). The hidden side of the work: Teacher knowledge and learning to teach. Language Teaching, 35, 1-13.

Freeman, D. (2007). Research "fitting" practice: Firth and Wagner, classroom language teaching, and language teacher education. The Modern Language Journal, 91, 893-906.

Freeman, D., \& Johnson, K. E. (1998). Reconceptualizing the knowledge-base of language teacher education. TESOL Quarterly, 32(3), 397-417.

Freeman, D., \& Johnson, K. E. (2004). Common misconceptions about the "quiet revolution": A response to Yates and Muchisky. TESOL Quarterly, 38, 119-127.

Fullan, M. (2007). The new meaning of educational change (4th ed.). New York: Teachers College Press.

Gass, S. (1995). Learning and teaching: The necessary intersection. In F. Eckamn, D. Highland, P. Lee, J. Mileham, \& R. Weber (Eds.). Second Language Acquisition Theory and Pedagogy. New Jersey: Lawrence Erlbaum. pp. 3-20.

Geertz, C. (1973). The interpretation of cultures. New York: Basic Books.

Gencer, A. S., \& Cakiroglu, J. (2007). Turkish preservice science teachers' efficacy beliefs regarding science teaching and their beliefs about classroom management. Teaching and Teacher Education, 23, 664-675.

Gibbs, G. R. (2007). Analyzing qualitative data. In U. Flick (Ed.). The Sage Qualitative research kit. London: Sage.

Grabe, W., Stoller, F. L., \& Tardy, C. (2000). Disciplinary knowledge as a foundation for teacher preperation. In J. K. Hall, \& W. G. Eggington (Eds.), The sociopolitics of English language teaching. New York: Multilingual Matters. pp. 178-194

Grosse, C. U. (1991). The TESOL methods course. TESOL Quarterly, 25(1), 29-49.

Haider, H., \& Frensch, P. (1996). The role of information reduction in skill acquisition. Cognitive Psychology, 30, 304-337.

Harmer, J. (2007). The practice of English language teaching: An introduction to the practice of English language teaching (4th ed.). Harlow: Longman.

Hastings, W., \& Squires, D. (2002). Restructuring and reculturing: Practicum supervision as professional development for teachers. Asia-Pacific Journal of Teacher Education, 30(1), 79-91. 
Hawkins, M., \& Norton, B. (2009). Critical language teacher education. In A. Burns \& J. C. Richards (Eds.), The Cambridge guide to second language teacher education. Cambridge: Cambridge University Press. pp. 30-39

Head, K., \& Taylor, P. (1997). Readings in teacher development. Oxford: Heineman English Language Teaching.

Hill, K., \& Sabet, M. (2009). Dynamic speaking assessment. TESOL Quarterly, 43(3), 537-545.

Hutchinson, T., \& Waters, A. (1987). English for specific purposes: A learning centered approach. Cambridge: Cambridge University Press.

Huxley, A. (1932). Brave New World. Retrieved from http://www.amazon.com/Brave-New-World-AldousHuxley/dp/0060929871

Ishihara, N. (2010). Instructional Pragmatics: Bridging Teaching, Research, and Teacher Education. Language and Linguistics Compass, 4(10), 938-953. doi: 10.1111/j.1749-818x.2010.00242.x

Johnson, K. E. (2006). The sociocultural turn and its challenges for second language teacher education. TESOL Quarterly, 40(1), 235-257.

Johnson, K. E. (2009). Second language teacher education: A sociocultural perspective. New York: Routledge.

Johnson, T., \& Kroksmark, T. (2004). Teachers' intuition-in-action: How teachers experience action. Reflective Practice, 5(3), 358-381.

Katz, S., \& Watzinger-Tharp, J. (2005). Towards an understanding of applied linguists in foreign language departments. Modern Language Journal, 89, 490-502.

Kimchi, J., Polivka, B., \& Stevenson, J. (1991). Triangulation: Operational definitions. Nursing Research, 40(6), 364-366.

Kozulin, A. (2009). New reference points for Dynamic Assessment (DA): A commentary on Karpov and Tzuriel. Journal of Cognitive Education and Psychology, 8(3), 242-245.

Kumaravadivelu, B. (1994). The post-method condition: Emerging strategies for second/foreign language teaching. TESOL Quarterly, 28, 27-48.

Kumaravadivelu, B. (2001). Toward a post-method pedagogy. TESOL Quarterly, 35, 537-560.

Kumaravadivelu, B. (2003). Critical language pedagogy, a post method perspective on English language teaching. World Englishes, 22, 539-550.

Kynäslahti, H., Kansanen, P., Jyrhämä, R., Krokfors, L, Maaranen, K., \& Toom, A. (2006). The multimode programme as a variation of research-based teacher education. Teaching and Teacher Education, 22, 246-256.

Lantolf, J. P., \& Poehner, M. E. (2004). Dynamic assessment of L2 development: Bringing the past into the future. Journal of Applied Linguistics, 1, 49-72.

Lantolf, J. P., \& Poehner, M. E. (2010). Dynamic assessment in the classroom: Vygotskian praxis for second language development. Language Teaching Research, 15(1), 11-33.

Lantolf, J. P., \& Thorne, S. L. (2006). Sociocultural theory and the genesis of second language development. Oxford: Oxford University Press.

Larsen-Freeman, D. (1983). Training teachers or educating a teacher. In J. Alatis, H. H. Strern, \& P. Strevens (Eds.), Applied linguistics and preparation of second language teachers: Towards a rationale. Washington: Georgetown University Press. pp. 264-274.

Larsen-Freeman, D., \& Anderson, M. (2011). Techniques and principles in language teaching ( $3^{\text {rd }}$ ed.). Oxford: Oxford University Press.

Lidz, C. S. (1991). Practitioner's guide to dynamic assessment. New York: Guilford Press.

Lincoln, Y. S., \& Guba, E. G. (2000). Paradigmatic controversies, contradictions, and emerging confluences. In N. K. Denzin \& Y. S. Lincoln (Eds.), Handbook of qualitative research (3rd ed.). London: Sage. pp.191-216 
Lynch, B. K. (2003). Language assessment and programme evaluation. Edinburgh: Edinburgh University Press.

Mackey, A., \& Gass, S. M. (Eds). (2012). Research methods in second language acquisition. West Sussex: Wiley-Blackwell.

Malderez, A., Hobson, A., Tracey, L., \& Kerr, K. (2007). Becoming a student teacher: Core features of the experience. European Journal of Teacher Education, 30, 225-248.

McLaughlin, D., \& Hanifin, P. (1995). Reflection, rhetoric or reality: A case study in preservice teacher education. Australian Journal of Teacher Education, 20(1), 36-44.

McLaughlin, M. W., \& Talbert, J. E. (1993). Contexts that matter for teaching and learning. Stanford, CA: Center for Research on the Context of Secondary School Teaching.

Miles, M. B., \& Huberman, A. M. (1994). Qualitative data analysis: A sourcebook of new methods. Thousand Oaks, CA: Sage.

Miller, J. (2009). Teacher identity. In A. Burns \& J. C. Richards (Eds.), The Cambridge guide to second language teacher education (pp. 172-181). Cambridge: Cambridge University Press.

Mulholland, J., Dorman, J. P., \& Odgers, B. M. (2004). Assessment of science teaching efficacy of preservice teachers in an Australian university. Journal of Science Teacher Education, 15(4), 313-331.

Murray. S., Nuttall, J., \& Mitchell, J. (2008). Research into initial teacher education in Australia: A survey of the literature 1995-2004. Teaching and Teacher Education, 24, 225-239.

Norton, B. (2005). Towards a model of critical language teacher education. Language Issues, 17(1), 12-16.

Nuland, S. V. (2011). Teacher education in Canada. Journal of Education for Teaching, 37(4), 409-421.

Nunan, D. (1991). Language teaching methodology: A textbook for teachers. London: Prentice Hall.

Ortega, L. (2005). For what and for whom is our research? The ethical as transformational lens in instructed SLA. Modern Language Journal, 89, 427-443.

Pajares, M. F. (1992). Teachers' beliefs and educational research: Clearing up the messy construct. Review of Educational Research, 62, 307-332.

Pavlenko, A. (2003). I never knew I was a bilingual: Re-imagining teacher identities in TESOL. Journal of Language, Identity, and Education, 2(4), 251-268.

Peacock, M. (2009). The evaluation of foreign-language-teacher education programmes. Language Teaching Research, 13(3), 259-278.

Poehner, M. E. (2007). Beyond the test: L2 dynamic assessment and the transcendence of mediated learning. The Modern Language Journal, 91(3), 323-340.

Poehner, M. E. (2008). Dynamic assessment: A Vygotskian approach to understanding and promoting L2 development. New York: Springer.

Poehner, M. E. (2011a). Dynamic Assessment: Fairness through the prism of mediation. Assessment in Education: Principles, Policy \& Practice, 18(2), 99-112.

Poehner, M. E. (2011b). Validity and interaction in the ZPD: Interpreting learner development through L2 Dynamic Assessment. International Journal of Applied Linguistics, 21(2), 244-263.

Poehner, M. E., \& van Compernolle, R., A. (2011). Frames of interaction in Dynamic Assessment: Developmental diagnoses of second language learning. Assessment in Education: Principles, Policy \& Practice, 18(2), 183-198.

Popko, J. (2005). How MA-TESOL students use knowledge about language in teaching ESL classes. In N. Bartels (Ed.), Applied linguistics and language teacher education. New York: Springer. pp. 387-404

Prabhu, N. S. (1990). There is no best method-Why? TESOL Quarterly, 24(2), 161-176.

Raviv, A., Raviv, A., \& Reisel, M. (1990). Teachers and students: Two different perspectives?! Measuring social climate in the classroom. American Educational Research Journal, 27(1), 141-157. 
Rea-Dickins, P. (2004). Understanding teachers as agents of assessment. Language Testing, 21, 249-258.

Rea-Dickins, P., \& Germaine, K. P. (1998). The price of everything and the value of nothing: Trends in language programme evaluation. In P. Rea-Dickins \& K. P. Germaine (Eds.), Managing evaluation and innovation in language teaching: Building bridges (pp. 3-19). London: Longman.

Richards, J. C., \& Renandya, W. A. (Eds). (2002). Methodology in language teaching: An anthology of current practice. Cambridge: Cambridge University Press.

Richards, J. C., \& Rodgers, T. S. (2001). Approaches and methods in language teaching (2nd ed.). Cambridge: Cambridge University Press.

Risko, V. J., Roller, C. M., Cummins, C., Bean, R. M., Block, C. C., Anders, P. L., \& Flood, J. (2008). A critical analysis of research on reading teacher education. Reading Research Quarterly, 43(3), 252-288.

Risko, V. J., Vukelich, C., \& Roskos, K. (2002). Preparing teachers for reflective practice: Intentions, contradictions, and possibilities. Language Arts Journal, 80(2), 134-144.

Rogoff, B. (2003). The cultural nature of human development. Oxford: Oxford University Press.

Rosenholtz, S. (1989). Teacher' workplace: The social organization of schools. New York: Longman.

Ryan, A. M., \& Patrick, H. (2001). The classroom social environment and changes in adolescents' motivation and engagement during middle school. American Educational Research Journal, 38(2), 437-460.

Sarason, S. B., \& Doris, J. (1979). Educational handicap, public policy, and social history. New York: Free Press.

Schön, D. A. (1983). The reflective practitioner: How professionals think in actions. USA: Basic Books Inc.

Schön, D. (1987). Educating the reflective practitioner: Toward a new design for teaching and learning in the professions. San Francisco: Jossey-Bass.

Shabani, K., Khatib, M., \& Ebadi, S. (2010). Vygotsky's zone of proximal development: Instructional implications and teachers' professional development. English Language Teaching, 3(4), 237-248.

Shrestha, P., \& Coffin, C. (2012). Dynamic assessment, tutor mediation and academic writing development. Assessing Writing, 17, 55-70.

Smith, K. (2005). New methods and perspectives on teacher evaluation. In D. Beijaard, P. C. Meijer, G. Morine-Dershimer, \& H. Tillema (Eds.), Teacher professional development in changing conditions. Netherlands: Springer. pp. 95-114

Taggart, G. L., \& Wilson, A. P. (2005). Promoting reflective thinking in teachers (2nd ed.). California: Crown Press.

Tierney, R. D. (2006). Changing practices: Influences on classroom assessment. Assessment in Education, 13(3), 239-264.

Tom, A. (1980). Teaching as a craft model: A metaphor for teaching and teacher education. Curriculum Inquiry, 10, 317-323.

Tomlinson, B. (Ed.). (2011). Materials development in language teaching ( $2^{\text {nd }}$ ed.). Cambridge: Cambridge University Press.

Tsu, A. B. M. (2005). Expertise in Teaching: Perspectives and Issues. In K. Johnson (Ed.), Expertise in Second Language Learning and Teaching (pp. 167-189). Houndmills: Palgrave Mcmillan.

Van Compernolle, R. A., \& Kinginger, C. (2013). Promoting metapragmatic development through assessment in the zone of proximal development. Language Teaching Research, 17(3) 282-302.

Vygotsky, L. S. (1997). Educational psychology. Boca Raton, FL: St. Lucie Press.

Vygotsky, L. S. (1998). The problem of age. In R.W. Rieber (Ed.), The collected works of L. S. Vygotsky, Vol. 5: Child psychology (pp. 187-205). New York: Plenum Press.

Walberg, H. (1977). Decision and perception: New constructs for research on teaching effects. Cambridge Journal of Education, 7, 12-20. 
Wallace, M. J. (1991). Training foreign language teachers: A reflective approach. Cambridge: Cambridge University Press.

Warford, M. K. (2010). The zone of proximal teacher development. Teaching and Teacher Education, 27(2), $252-258$.

White, B., \& Le Cornu, R. (2002). Email reducing stress for student teachers. Education and Information Technologies, 7(4), 351-357.

Williams, M., \& Burden, R. L. (1997). Psychology for language teachers: A social constructive approach. Cambridge: Cambridge University Press.

Wright, T. (2002). Doing language awareness: Issues for language study in language teacher education. In H. Trappes-Lomax \& G. Ferguson (Eds.), Language in language teacher education. Amsterdam: John Benjamins Publishing Company. pp. 113-130.

Yarrow, A., Millwater, J., \& Foster, B. (1996). University practicum supervisors: Marching to a different drummer? Asia-Pacific Journal of Teacher Education, 24(2), 197-212.

Yeomans, J. (2008). Dynamic assessment practice: Some suggestions for ensuring follow up. Educational Psychology in Practice, 24(2), 105-114. doi: 10.1080/02667360802076107

Yin, R. K. (2003) Case study research: Design and methods ( $2^{\text {nd }}$ ed.). Thousand Oaks, CA: Sage.

Yuen-Kwan, W. N. (1998). ¿How sustainable are in-service teacher training courses? Asia-Pacific Journal of Teacher Education, 26(1), 65-73.

Zeichner, K. M. (1983). Alternative paradigms of teacher education. Journal of Teacher Education, 34(3), 3-9.

Received: 08/03/2016

Accepted: 15/05/2016 
Appendix 1: The questionnaire which was administered to gather trainee teachers' opinions about TTC's held in Iran Directions: For each statement below, please mark the response that best describes your opinion of the Teacher Training Course you took. There is no right or wrong answer; so, please respond as honestly as possible. Thank you!

\begin{tabular}{|c|c|c|c|c|c|}
\hline The TTC ... & $\begin{array}{l}\text { Strongly } \\
\text { Agree }\end{array}$ & Agree & $\begin{array}{l}\text { Neither Agree } \\
\text { Nor Disagree }\end{array}$ & Disagree & $\begin{array}{l}\text { Strongly } \\
\text { Disagree }\end{array}$ \\
\hline 1....had good linkage between different teaching components. & 5 & 4 & 3 & 2 & 1 \\
\hline $\begin{array}{l}\text { 2. ...avoided overlapping information between different teaching } \\
\text { components. }\end{array}$ & 5 & 4 & 3 & 2 & 1 \\
\hline 3. ...gave me adequate training in English Language Teaching. & 5 & 4 & 3 & 2 & 1 \\
\hline 4. ...gave me adequate training in teaching all the four skills. & 5 & 4 & 3 & 2 & 1 \\
\hline $\begin{array}{l}\text { 5. ... gave me adequate training for the needs of the local context } \\
\text { (teaching in English institutes in Iran). }\end{array}$ & 5 & 4 & 3 & 2 & 1 \\
\hline 6. ...was up-to-date. & 5 & 4 & 3 & 2 & 1 \\
\hline 7. ...taught me how to give feedback on my students' writing. & 5 & 4 & 3 & 2 & 1 \\
\hline $\begin{array}{l}\text { 8. ...encouraged me to reflect on my past experiences as a language } \\
\text { learner. }\end{array}$ & 5 & 4 & 3 & 2 & 1 \\
\hline 9. ...encouraged me to be a reflective teacher (when I start teaching). & 5 & 4 & 3 & 2 & 1 \\
\hline $\begin{array}{l}\text { 10.... promoted flexibility in using different teaching practices for different } \\
\text { situations. }\end{array}$ & 5 & 4 & 3 & 2 & 1 \\
\hline $\begin{array}{l}\text { 11. ...balanced teacher-centered and student-centered learning on its } \\
\text { teachings. }\end{array}$ & 5 & 4 & 3 & 2 & 1 \\
\hline $\begin{array}{l}\text { 12. ...taught me how to evaluate my students' progress and abilities in } \\
\text { writing. }\end{array}$ & 5 & 4 & 3 & 2 & 1 \\
\hline 13. ...taught me how to help my students develop their language abilities. & 5 & 4 & 3 & 2 & 1 \\
\hline 14. ...taught me how to evaluate myself as a teacher. & 5 & 4 & 3 & 2 & 1 \\
\hline 15. ...taught me classroom management skills. & 5 & 4 & 3 & 2 & 1 \\
\hline 16. ...taught me how to use foreign language teaching materials. & 5 & 4 & 3 & 2 & 1 \\
\hline 17...taught me how to adapt foreign language teaching materials. & 5 & 4 & 3 & 2 & 1 \\
\hline 18. ... increased my powers of self-evaluation. & 5 & 4 & 3 & 2 & 1 \\
\hline 19. ...taught me foreign language assessment skills. & 5 & 4 & 3 & 2 & 1 \\
\hline $20 . .$. taught me how to integrate instruction with assessment. & 5 & 4 & 3 & 2 & 1 \\
\hline 21. ...was relevant to my needs. & 5 & 4 & 3 & 2 & 1 \\
\hline $\begin{array}{l}\text { 22. ...had a good balance between the teaching of: the main skills, } \\
\text { language assessment techniques, and classroom management skills. }\end{array}$ & 5 & 4 & 3 & 2 & 1 \\
\hline 23. ...prepared me to teach English in the classroom. & 5 & 4 & 3 & 2 & 1 \\
\hline 24. ...met my needs. & 5 & 4 & 3 & 2 & 1 \\
\hline 25. By the end of the TTC, I will be ready to teach English. & 5 & 4 & 3 & 2 & 1 \\
\hline
\end{tabular}

26. Is there a specific language skill (listening, speaking, writing, or/and reading) on which you wish you had been provided with more instructions? Please elaborate on your answer.

27. What (positive/negative) comments can you make about the course you took? 
Appendix 2: The interview protocol which was used to elicit TTC instructors' opinions on the shortcomings and merits of the courses and seek their suggestions for further improvement on existing syllabi and procedures

Dear TTC instructor,

Please give an account of what you think about the following aspects of the TTC you ran:

(a) Your opinions on the strengths of the course,

(b) Your idea about the weaknesses of the course,

(c) Your views on possible ways to refurbish/improve the course, and

(d) Your opinions on the alignment and relevance of research findings to the syllabi, content and instruction of the course. Are you familiar with the underlying assumptions of Dynamic Assessment (DA), which can be implemented in classroom contexts? If yes, do you think it is worth instructing preservice teachers in DA? Why?

Thank you very much for your time and cooperation. 